From accountability to digital data: the rise and rise of educational governance Accepted for publication in Review of Education on 28 June 2018.

Cate Watson

University of Stirling

Cate.watson@stir.ac.uk 


\title{
From accountability to digital data: the rise and rise of educational governance
}

\author{
Abstract \\ Research interest in educational governance has increased in recent years with the rise to \\ prominence of transnational organisations such as the OECD and the importance attached \\ to international comparison of educational systems. However, rarely do educational \\ researchers consider the historical antecedents that have attended these developments. Yet \\ to more fully appreciate where we are now it is necessary to examine the national and \\ global events that have shaped the current policy context. This paper presents a review of \\ educational governance in the UK from the 1970 s seeing in this a trajectory from the \\ emergence of accountability to today's overriding concern with digital data. In doing this, \\ the paper aims to go beyond providing a historical account, rather its purpose is to shed \\ light on educational change; and further, to analyse the contribution of educational \\ research to an understanding of events as they have unfolded over the past five decades. \\ While it is necessarily rooted within the particular historical context of the UK it can be read \\ as an analysis of the factors influencing educational change in the context of globalised \\ policy spaces more broadly. A recurrent theme is the appearance of the 'unanticipated \\ consequence', one of the most important issues the social sciences has to contend with. \\ Thus a tentative theory of ironic reversal as a source of policy failure emerges which is not \\ only of relevance to educational policy but of wider significance.
}

\section{Introduction}

Since its rediscovery in the 1980s governance, or what is commonly referred to as the 'new' governance, has become 'a hot topic for ivory tower academics' (Jessop, 2003, p.101). Governance has been taken up and deployed in countless ways by academics across the various disciplines of the social sciences, becoming among other things 'an approach, a theory and a perspective' but also a buzzword, a fetish, a fad and, as a result of all this, an empty signifier (Levi-Faur, 2012, p.3). In fact, governance has become the subject of a fullyfledged 'turn', assisted no doubt, by the very ambiguity that invariably attends the term. Within this turn education, and its successor 'learning' (Ozga et al, 2012, p.85), occupy a central role. Governance of national education systems has become a global concern but in 
addition governance, considered as an effect of networks, can itself be conceived as a process of learning.

While consensus may be hard to achieve, as a starting point 'new' governance may be defined as,

an account of social coordination in terms of the ways in which disparate actors within civil society come together in networks by means of dialogue and a sharing of resources. (Bevir and Trentmann, 2004, p.10)

This conceptualisation of governance as a form of networking emerges in response to the complexity of modern systems of organisation, in which 'multiple actors operating at different levels are more fluid and open to negotiation' (Organisation for Economic Cooperation and Development, 2016, p.17). As a result of this complexity the governance of education systems has become a policy priority centred around the key themes of accountability, capacity building, and strategic thinking (OECD, 2016).

This paper constitutes a historical review of the research literature on educational governance in the UK compulsory education sector since the 1970s - and asks, at what point did a concern with governance begin to occupy educational researchers and why? In so doing I situate education within the wider domain of governance research in order to emphasise connections within the policy field more broadly; in this way I address the criticism that much educational research is divorced from wider social concerns (Ball, 1997). The paper is structured as follows. First, I trace the emergence of 'the new governance' (Peters, 2012). The etymology of governance is related to 'steering' - people can be steered by freedom to choose (Rhodes, 1996) hence, the governance turn is inextricably bound up with economic shifts evident in the late 1970s and early 1980s and the turn to neoliberalism and faith in the market. Next, I briefly set out the political context in which these new constructs of governance came to the fore in the UK education system before turning to an examination of the research literature from the 1970s to the present day. In doing this, the paper aims to go beyond providing a historical account, rather it aims to shed light on educational change, 'as a phenomenon which is negotiated in an institutional context under pressure from economic, social and bureaucratic dynamics' (Salter and Tapper, 1981, p.8); 
and further, to analyse the contribution of educational research to an understanding of events as they unfolded, tracing the trajectories of governance over the past five decades. So, while the paper is necessarily rooted within the particular historical context of the UK it can be read as an analysis of the factors influencing educational change in globalised policy spaces more broadly. A recurrent theme in the analysis that follows is the appearance of the 'unanticipated consequence', which Merton (1936) regards as one of the most important issues the social sciences has to contend with. Thus, a tentative theory of ironic reversal as a source of policy failure emerges which is not only of relevance to educational policy but of wider significance.

\section{The turn to governance}

The prevalent narrative around the shift to neoliberalism in the global West has it that neocon think tanks, based around the thinking of economists such as Friedrich von Hayek and Milton Friedman, were only biding their time waiting for the most propitious moment to persuade politicians that the fundamentally self-correcting nature of markets would ensure not only the most efficient way of providing goods and services but also morally the most equitable way of doing so. Such a moment presented itself with the apparent failure of Keynesian Welfarism in the 1970s, which had centred on the belief (misappropriated from Keynes) that interventionist governments could spend their way out of recession. In opposition to this advocates of neoliberalism argued for a rolling back of the functions of the state thereby leaving organisations free to pursue their interests unfettered by government interference. Neoliberalism, especially in these early days of 'experimental proto-neoliberalism' (Peck and Tickell, 2002, p.384) is thus associated with aspirations to reduce both the size of government and its reach (Cahill, 2013).

However, it is apparent that far from reducing the role of the State, neoliberalism has resulted in the expansion of government and the extension of governance into the global sphere This, as Levi-Faur and Jordana (2005) point out, is the paradox of neoliberalism (and a monument to the law of unintended consequences). However, Peck and Tickell (2002, p.384) caution against a simplistic view which sees neoliberalism as either 'monolithic in form or universal in effect'. They point to a complex evolution, from its inception in the 1970 s, through the aggressive 'roll-back neoliberalism' of the 1980 s to 'an ascendant 
moment of "roll-out" neoliberalism', followed by the 'soft' neoliberalism that underpinned the Third Way politics of successive UK New Labour governments of the 2000s (leading these authors, perhaps prematurely, to argue that neoliberalism has become 'naturalised'):

In the course of this shift, the agenda has gradually moved from one preoccupied with the active destruction and discreditation of Keynesian-welfarist and socialcollectivist institutions (broadly defined) to one focused on the purposeful construction and consolidation of neoliberalized state forms, modes of governance, and regulatory relations. (Peck and Tickell, 2002, p.384)

Arguably, it is the shift to a focus on 'regulatory relations' - and more especially the complexity brought about by regulation at a distance - that has been responsible for the rise to prominence of governance as a theory of political science. The 'new' governance is widely understood as a response to the failure of both top down command and control government and unregulated markets. Lobel $(2012$, p.67) argues that increased participation of non-state actors is recognition of the complexity of modern polities and the need to draw on a range of expertise and 'create internal norms' among a range of stakeholders. Public-private collaboration, diversity, and decentralisation follow from this initial premise. In this new governance model 'individuals are norm-generating subjects involved in the process of developing and changing the norms of behaviour, in contrast to the traditional model, under which private actors are the objects of regulation' (Lobel, 2012, p.67). This model requires actors to be adaptable and engaged in a constant process of learning, steered by 'soft laws' and non-coercive means aimed at participation and dialogue. The 'new governance' can therefore be positioned as an aid to a flourishing democracy, in which regulation becomes a collective endeavour. In this system 'power is not so much a matter of imposing constraints upon citizens as of "making up" citizens capable of bearing a kind of regulated freedom' (Rose and Miller, 1992, p.174). The emergence of regulatory regimes supported by these conceptualisations of governance does indeed suppose a naturalised and somewhat benign neoliberalism, its true intent obscured to all (with the exception of dyed-in-the-wool Bourdieusian academics, naturally). Governance thus operationalises the regulatory functions of the neoliberalised state and hence governance and neoliberalism are intricately entangled and co-emergent. 


\section{Moving towards governance}

The 1970s was a paradoxical decade characterised by political instability, industrial unrest and an overall sense that we were going down the pan but also by indulgence, lack of surveillance, and a certain innocence. The Conservative government, led by Edward Heath, was in office from 1970-1974. During this time the UK joined the European Economic Community and things ticked along nicely until the oil crisis of $1973 / 74$, caused by the embargo of oil exports imposed by the Organization of Arab Petroleum Exporting Countries on countries deemed to have supported Israel in the Yom Kippur War (1973). The embargo resulted in a severe shock to the economy. So severe, indeed, that from January to March 1974 much of the UK workforce was placed on a '3-day week'. The election called by Heath in February 1974 produced no overall control and a minority Labour government was formed under Harold Wilson. A second election followed in October of the same year giving Wilson a slender majority of three. Wilson unexpectedly stepped down in 1976 and James Callaghan became prime minister (PM). Having by this time lost his majority he was forced into an arrangement with the Liberal party known as the 'Lib Lab Pact' (1977-1978). This lasted until 1979 which saw the election of Conservative PM Margaret Thatcher.

There is a metaphoric (if illusory) neatness in being able to ascribe a 'turn' to a crisis. The crisis which gave birth to the governance turn in the UK was one of both legitimation and rationality (Habermas, 1973) as played out in the 1970s and particularly in the dying days of the Labour Callaghan administration (1976-1979). Ball (1997) berates education researchers for a myopic tendency to see education as somehow unconnected to other areas of social/economic policy but in the crises that beset the UK in the 1970s the involvement of education was hard to ignore. That knowledge as a commodity is what secures economic success is one of the 'modern myths' that underpin education policy (O'Hagan, 1999). It follows then that 'if the economy was in decline education had demonstrably not come up with the goods' (Troman, 1989, p.280). This intensified the doubts that had begun to circulate around education and the 'progressive theories' popularly supposed to have taken hold in State comprehensive schools, in England and Wales at least, in the 1960s.

This apparent failure of the education system resulted in a crisis of legitimation. But further, since the government was forced to make cuts to public expenditure, of which education had to bear its share, following the humiliating $\$ 3.9$ billion loan from the International 
Monetary Fund in 1976, there arose a crisis of rationality which demanded that education would have to deliver more with less (a familiar mantra). As Troman observes, if 'economic retrenchment' was foisted on an unwilling Callaghan, it was taken up with alacrity by the Thatcher government that inevitably followed the industrial unrest of the 'Winter of Discontent' (1978-9) during which the end of Welfarism was metaphorically and powerfully enacted as the dead went unburied and rubbish piled up in the streets. Habermas characterises capitalism as an inherently crisis-driven process in which solutions to problems inevitably create new problems. Crises in this sense herald (temporary) salvation and for education this salvation was to be found with the alignment of rationality and legitimation in moves towards increased regulatory control which required a profound shift in systems of governance.

This then provides the starting point for the analysis presented here which examines trends in the educational research literature around issues of governance in the UK education system over the past five decades.

\section{Governance in the 1970s: the rise of accountability}

There is little use of the term 'governance' in any UK education research journal in the 1970s, and where it is used it tends to be applied at the institutional level of the school. What is evident, however, is a growing concern with accountability, a key theme in present day constructs of governance (OECD, 2016). By the end of the 1970s Halpin (1979, p.199) notes that accountability had 'become one of education's new catchwords'. A sentiment echoed by MacDonald (1979) and Watson (1978). There was, Halpin (1979) asserts, a consensus at all levels of the education system that schools and teachers should be accountable for their actions. However, beyond this there was little agreement as to what form such accountability should take, to what or whom it should be directed, or even around the meaning of the word itself. Where policy-makers tend to gloss over such niceties as this educationists take a more nuanced view. Halpin's article focuses on the distinction between 'offering an account' and 'being accountable'. The former, Halpin argues, is 'akin to being answerable [and] does not necessarily entail liability to sanction, whereas the latter is of quite a different order - it wants to know if certain obligations have 
been met, and does entail potential liability to sanction' (Halpin, 1979, p.201). Policy neatly elides these meanings in the service of legitimation.

Although the 'accountability movement' (MacDonald, 1974) took hold in the 1970 s it did not start there. Like much else, the concept came to us from America where 'management by objectives' had become familiar practice in the private and public sectors in the 1960s (Kogan, 1984). In the UK this trend became evident in a number of moves designed to end the amateurish nature and secrecy of many of the UK's most cherished institutions. Thus, for example, the Fulton Report on the Civil Service advocated the introduction of principles of 'accountable management'. According to which 'the performance of individuals (or units) is measured as objectively as possible, and those individuals (or units) are then held responsible for tasks they have performed' (HMSO, 1968). Unfortunately, many of the recommendations of the Fulton Report found resistance among the very group who were required to implement them and hence much of its force was lost (Kellner and CrowtherHunt, 1981). Similar recommendations emerged from the Bains Committee report (HMSO,1972) on local authority restructuring but were more successfully executed. Bains advocated greater corporate planning by local government and 'management by objectives', under the central control of the Chief Executive. An almost 'carbon copy' of the recommendations was produced in Scotland in the Paterson Report (HMSO, 1973, cited in Minogue, 1977).

These moves were widely perceived as posing a threat to the traditional autonomy of the chief education officer (Barnes, 1975; Blowers, 1977). At a time of plenty such concerns might not have arisen but in the straitened circumstances in which many local authorities found themselves opposition to restructuring was more vociferous. MacDonald (1979) argues that the context for accountability management shifted from, 'a means of informing uncontested investments and facilitating cooperative planning with other services to an unsympathetic audit of coveted expenditure' (p.10). This, he suggests, is important in understanding why many of those initially sympathetic towards the introduction of accountable management procedures subsequently turned against it.

On the other hand, the narrowly instrumental understanding of accountability as set out in the Bains Report led some eminent educationists (MacDonald cites among these Michael Eraut and John Elliott) to reject this 'early managerial prototype' (MacDonald, 1979, p.3). 
The antecedents of what came to be known as the New Public Management are clearly set out by Barnes (1975, p.15):

[corporate management] involves the application to education of management methods derived from other spheres and requiring the definition of objectives, progress towards which can be quantified within a short period of time. It requires a search for performance indicators which can be expressed arithmetically. And it carries the implication that the best people to devise, and perhaps to operate, new techniques of this kind are likely to be found outside the educational world, their ignorance of the atmosphere of schools and the traditions of the teaching profession being irrelevant or, in the view of extremists, positively advantageous.

However, as the decade and the concept developed, MacDonald (1979, p.1), says, 'accountability based on openness of process as an alternative to specification of product' found greater favour among educationists. Thus, MacDonald advocated a process model of school accountability centred on school 'self report'. Though he recognised that self reporting was generally regarded as of 'low credibility' in terms of the professional accountability of schools and teachers, it had merits and was, he argued, 'a long overdue social invention'. Elliott (1977, p.103) also took the view that 'Public accountability implies that the evaluated are obliged to evaluate themselves'. In the late 70 s the idea of selfevaluation was still a pioneering concept not yet taken up by policy-makers as a key instrument of performativity.

Elliott $(1979$, p.23) contended that the rationale for self-evaluation could be argued on three grounds which he referred to as social, economic and professional accountability. Social accounting is concerned with curriculum policies and 'social acceptability'; economic accounting concerns pupil performance and 'economic acceptability'; while professional accounting centres on pedagogies and 'educational acceptability'. Social and professional accountability, Elliott argued, were not necessarily antagonistic, requiring the kinds of qualitative 'illuminative evaluation' (Parlett and Hamilton, 1972) which had come to the fore in the 1970s. Economic accountability however required schools 'to see themselves as factories manufacturing clearly defined and measurable outputs in the form of "learning outcomes"' (Elliott, 1979, p.23). Economic accountability he argued, was incompatible with these other forms of self-evaluation and likely to produce 'a distorting effect...in a context of 
economic accountability the educative quality of teaching becomes an irrelevance' (p.25). MacDonald (1978) too offered a trenchant critique of what he termed 'technocratic accountability' describing this as a 'tunnel to dystopia' in which reductive measures of school output divorce schools from both the learning process and educational critique. However, it seems the government was in no mood to adopt more 'sensible' models of accountability (MacDonald, 1978) and the general feeling of dissatisfaction stoked up by politicians around the failure of the education system served to legitimate the technocratic/economic approach.

To some extent, academics could be regarded as contributing to this confusion around forms of accountability which played into the hands of the policy-makers for whom such proliferation of meaning is, if not exactly a virtue, certainly a convenience. MacDonald $(1979$, p.1) notes dryly, that accountability as a concept is 'susceptible to competing ideological suppositions' a susceptibility which continues to inhabit (some might say 'infect') the term to this day.

As the 1970s progressed, other concerns emerged that lent themselves to the accountability movement in education. Many of these were expressed in James Callaghan's Ruskin Speech which inaugurated the 'Great Debate' on education and signalled a change in the direction of Labour thinking around education. Callaghan (1976) said,

...there is the unease felt by parents and others about the new informal methods of teaching which seem to produce excellent results when they are in well-qualified hands but are much more dubious when they are not...My remarks are not a clarion call to Black Paper ${ }^{1}$ prejudices. We all know those who claim to defend standards but who in reality are simply seeking to defend old privileges and inequalities... It is not my intention to become enmeshed in such problems as whether there should be a basic curriculum with universal standards-although I am inclined to think there should be...

As Ginsburg et al (1979) note, the 'Great Debate' was framed in such a way that it prevented discussion around the aims and purposes of education in the current context. In this sense it was neither a Debate - nor was it particularly Great - but this is a familiar ploy of politicians engaged in 'consultation'. Instead Callaghan focused on ways to secure the 'improvements' 
needed to meet the needs of industry - greater centralised control, a core curriculum, monitoring, and national standards and assessments. Bogdanor (1979) argues that a major aim of the Great Debate was to enable the Department for Education and Science (DES) to regain control over curriculum and examinations. This control had been delegated to the Schools Council ${ }^{2}$ which, 'dominated as it was by the teachers' associations, had been unable to evolve a coherent policy on examinations which could secure general approval (Bogdanor, 1979, p.162).

The Great Debate was followed by the Green Paper Education in Schools: A Consultative Document (HMSO, 1977a). In the Green Paper, accountability is squarely concerned with pupil performance and a 'Growing recognition of the need for schools to demonstrate their accountability to the society which they serve [through] a coherent and soundly based means of assessment for the educational system as a whole, for schools, and for individual pupils' (HMSO, 1977a, p.16). A different slant on the accountability movement was provided by the Taylor Report (HMSO, 1977b), A New Partnership for Our Schools, which largely saw the issue of accountability in terms of changes to school governing bodies and the need for increased representation of parents and the wider community on school boards. Though widely cited the Taylor Report drew a mixed response, with Owen (1978, p.37) noting that it 'gives the impression of describing the Emperor's clothes. Is there much new to be said?' It is true that the Taylor Report was not the first to examine the relationship between schools and parents (the issue of greater parental partnership had formed a major plank of the earlier Plowden Report, HMSO,1967). However, what was new was the challenge it presented to the professional autonomy of teachers in proposing that parents have a greater say in setting the aims of the school and in matters of the curriculum. With the benefit of hindsight, Bridges (1994, p.67) concluded that 'The Taylor Report was a wise and carefully balanced document, which deserved more sustained government support than it was in the end to receive'. Its misfortune was to report at a time of political change with its key messages being open to a different interpretation by the Conservative Government that came to power in 1979. In any event, Taylor admitted that where his proposals had been implemented 'they have created more difficulties than opportunities' (quoted in Bennett, 1984, p.162). 
The Taylor Report rehearsed the now familiar theme around the need for more openness in British institutions (as both the Fulton and Bains reports had done). The charge of secrecy had also been directed towards national government. The growing concern with accountability was given added impetus as a result of an OECD report published in 1975 which was highly critical of the DES and its arcane policy-making, advocating more open and democratic approaches. The DES responded by 'fashioning a change of role for the traditionally secretive and largely advisory inspectorate' (MacDonald, 1979,p.18), upping the ante by publishing evaluations, and expanding the work of the Assessment of Performance Unit (APU) established in 1974 to monitor teaching standards. In this way, with some irony, the greater openness advocated by the OECD paved the way for more centralised control.

An additional justification for government action around perceived standards was provided by the notorious 1996 'William Tyndale affair'. William Tyndale was a primary school in Islington whose 'radical' teaching methods led to parent protests - a response, which MacDonald (1979, p.18) suggests constituted 'an unprecedented threat to public apathy'. The William Tyndale affair illustrated all too graphically how 'the pursuit of national economic goals could not be merely ignored but actually frustrated in a system where clear central leadership was absent' (Dale, 1981, p.310). The events were subsequently narrated as instrumental in the turn to government control over the curriculum. ${ }^{3}$ The twin pressures exerted by government and parents, produced, MacDonald (1979) argues, 'a conceptual and operational confusion between the notion of accountability as a condition of autonomy and the notion of power-sharing as an expression of accountability' (p.18). Certainly, there was an ideological slipperiness around the term which enabled Watson (1978) to comment favourably that:

The concept is undoubtedly linked with those of democratization, political rights, and demands by parental pressure groups such as the Home-School council and various Parent Teacher Associations for greater involvement in and even control of education. (Watson, 1978, p.10)

Conversely, others saw it as a means by which government might exert unwarranted control over the teaching profession and as threat to the traditional autonomy of the 'head master' (Boynton, 1975, p.11). 


\section{Parental choice}

As the Taylor report noted, closely entwined with issues of accountability was a concern with parental involvement in schools. However, this could also be construed within different discourses. Thus, as Bogdanor (1976) notes, calls for parental involvement took two forms: greater participation and say for parents in the governance of education through more open access to information and representation on school boards, as advocated in the Taylor Report; and the positioning of parents as consumers in moves towards marketisation of the education system, particularly through the appeal to 'parental choice'. In the US a major debate was taking place around the introduction of voucher schemes as a means to operationalise parental choice driven, as in the UK, through concern with declining standards (Mason, 1975). It was commonly claimed that such ideas gained ground in the US due to the crisis sparked by the launch of the Russian satellite, Sputnik, signalling a hitherto unthinkable superiority in Russian technological capability. The introduction of voucher schemes was predicated on the ideas expressed in Milton Friedman's Capitalism and Freedom (1962) that 'Schools should be denationalized and subject to classical market place theories of demand and supply' (Mason, 1975, p.161). A Friedman-style unfettered market was never envisaged however, even in the USA, with various models proposed each embodying different degrees and types of market manipulation. At no time were such schemes touted in the UK as a serious proposition, though Kent LEA carried out a feasibility study (Hansard, 1978). Seldon (1979) reports on this favourably, and interestingly argues that the scheme was favoured by a number of Labour academics but was vetoed by the then Labour Education Secretary, Shirley Williams. More surprisingly vouchers were not implemented by the incoming Conservative Education Secretary, Keith Joseph, despite his 'messianic' support for the idea (Chitty, 1997a); Joseph was apparently persuaded that the same results could be achieved by other means (West, 1982, np).

Ironically perhaps, the whole issue of parental choice only came to the fore with the introduction of the comprehensive system. Judge (1979) argues that prior to comprehensive secondary education (introduced in 1965) the selective 11+ examination had largely taken choice out of parents' hands. Though Judge notes that parental choice might be seen as undermining the aims of comprehensive education by widening the gap between good and bad schools, in certain local authorities in England parents were permitted to list schools in 
rank order. Although in some areas most parents received their first choice in others Benn (1974, p.68) notes with some cynicism what she refers to as 'guided parental choice': "guided" because only certain parents' choices-certainly for the academic comprehensives - can be honoured'. In any case, as Judge notes, the choice lay between good and bad and did not extend to choice over the kind of education provided which was moving, under James Callaghan's premiership, towards a more centralised approach with greater government control over the curriculum (Ginsburg et al, 1979). Even Conservative policy of the 1970s (while in opposition) did not go this far, regarding the proper responsibility of government as 'maintaining a continuous watch on the whole education system' while having 'no direct responsibility for what is taught in schools' (Bogdanor, 1976, p.122).

\section{The 1970s: summary}

What emerges from the literature in the 1970s is an intensity around the question of 'Who should control our schools?' (Glatter, 1976). This followed a lengthy period of relatively benign neglect of educational policy under the 1944 Education Act during which time it was assumed that 'to give clear definition to the powers and rights of different bodies is

undesirable, that vagueness and lack of definition usually "works"' (Glatter, 1976, p.51). This vagueness distributed responsibility between local education authorities (LEAs), governors and school heads, but as MacDonald argues, this desirable dispersion of powers was already under assault in the 1960s with moves to more corporate or entrepreneurial models following the expansion of local government. This gave rise to the 'accountability movement' which replaced a paternalistic obfuscation with a more muscular technocratic efficiency, in keeping with a renewal of emphasis on economic need. What is evident in the development of the accountability movement is the formation of a 'chain of equivalence' (Laclau and Mouffe, 2001) aligning those who saw it as a means to exert control over the education system and those who saw it as an aid to democratisation, which resulted in the dissolution of conflict in the coalescence of opposites. 
The end of the political consensus that had prevailed from the 1944 Education Act to the 1960s, coupled with the economic crisis of the 1970s provided the incoming Thatcher led Conservative administration in $1979^{4}$ with the rationale for a radical programme of change which with hindsight has been narrated as the embrace of neoliberalism and the rolling back of the state. In setting out Conservative thinking while in opposition Bogdanor (1976, p.120) argued that central government had become 'overloaded', 'clogged up with the huge variety of problems it is expected to solve'. Moreover, he went on, it is a mistake to assume that central government 'possesses some special knowledge or expertise enabling it to decide priorities for the whole country'. It follows from this reasoning that decision-making should be devolved from the centre. Crucially however, Bogdanor argues, LEAs were themselves implicated in the evident collapse of educational standards and were responsible for 'widespread popular alienation' (p.112) from local government. This necessitated increased accountability of LEAs that was to be achieved by two measures: monitoring of standards (including appraisal of performance); and measures to increase parental influence as the 'consumers' of education. This move to greater accountability thus provided the rationale for changes to governance structures, with central government holding local authorities to account for educational performance.

The essentials of Conservative ideology were set out in the campaign manifesto...

We will halt the Labour government's policies which have led to the destruction of good schools; keep those of proven worth; and repeal those sections of the 1976 Education Act which compel local authorities to reorganise along comprehensive lines and restrict their freedom to take up places at independent schools.

We shall promote higher standards of achievement in basic skills. The Government's Assessment of Performance Unit will set national standards in reading, writing and arithmetic, monitored by tests worked out with teachers and others and applied locally by education authorities. The Inspectorate will be strengthened. In teacher training there must be more emphasis on practical skills and on maintaining discipline. 
Extending parents' rights and responsibilities, including their right of choice, will also help raise standards by giving them greater influence over education. Our Parents' Charter will place a clear duty on government and local authorities to take account of parents' wishes when allocating children to schools, with a local appeals system for those dissatisfied. Schools will be required to publish prospectuses giving details of their examination and other results. (Margaret Thatcher Foundation, no date)

These election promises were enacted in the 1980/81 Education and Education (Scotland) Acts. As has been widely commented on by educational researchers, the construct of the consumer underpins the ideology of these Acts. Granting parents the right to express a preference for the school attended and basing this choice on the provision of information by the school including examination results, effectively created a market and marginalised LEAs without creating the need for a voucher system. ${ }^{5}$

Although somewhat more common than in the 1970s the term 'governance' is still little used in the UK research literature of the 1980s. Concern remains focused on accountability, but there is a clear shift in the meaning attached to the term. Thus, Ranson (1986) argues that the 1980/81 Acts embodied 'the assumptions of the market-place...Legislation enacted a distinctive form of accountability with the public conceived as consumers whose preference would improve the effectiveness of schools' (p.96). The shift to market accountability from professional accountability inevitably altered the relationship between schools and parents from client (subjected to the views and judgements of experts) to individual consumer.

The 1980 Act increased direct control and regulation of LEAs by the DES. Ranson (1985) comments that "the conjunction of extending the principles of "hierarchy" and "markets" has the designed effect of undermining the authority of the key partner of the past - the LEA' (Ranson, 1985, p.68). Thus, the government took back powers from the LEAs while at the same time demanding greater performative accountability. In this way, the 1980 Act constructed a paradoxical mix of 'centralising and decentralising instruments' which shifted regulation and in effect inaugurated the era of 'new' governance in all but name. (Ranson 
asks whether this shift was decisive, and concludes that we might have to wait a little to find out - with hindsight we can probably say that it was).

As part of the move towards marketisation of the system, the 1980 Act required schools and LEAs to provide more information to support parental choice of school. However, Munn (1985) asserts that the additional information to be provided to parents was of little interest to them. She reports on three research projects carried out in the late 1970s, all of which concluded that 'parents seem content to delegate to teachers decisions on a whole range of matters concerning schooling on the grounds of teachers' expertise' (p.106). Evidently, parents did not, at this stage, see themselves as consumers of education. However, Munn also says there were indications that perceptions around teacher expertise could inhibit parental challenge. Further, Ginsburg et al (1988) point to media coverage around this time which questioned teacher competence, offering this as 'an explanation of falling standards' (Ginsburg et al, 1988, p.329). Together, these factors created a tension which was effectively exploited by the market ideology producing 'a hothouse atmosphere of parents' rights' which furthered demands for accountability and encouraged 'teachers to seek refuge in their professional expertise as a means of safe-guarding their autonomy' (Munn 1985, p.108). The mistrust generated between increasingly entrenched sides (exacerbated by teacher unrest and industrial action) served to create a desire for more information, including the publication of league tables, where none had apparently existed before (Ginsburg et al, 1988). Munn concludes, 'by placing schools in direct competition with each other and emphasising parents' rights, it places home-school relationships in a combative framework...Far from promoting effective home-school communication, therefore, recent legislation is actively constraining it' (Munn, 1985, p.110).

The 1980 Act in England also contained provision for parents to become members of school governing boards (in Scotland this had to wait until the $1981 \mathrm{Act}$ ). This was extended in the Green Paper, Parental influence at school: a new framework of School Government in England and Wales (DES, 1984), which proposed that parents should be in the majority. Bennett (1984) points to the apparently paradoxical mix of central control and 'parental freedom' set out in the Green Paper which in effect created, he claimed, 'an alternative line of accountability' set against central government (Gray and Bennett, 1984, cited in 
Bennett, 1984, p.162). However, this ostensibly democratising move by government had the desired effect of further marginalising LEAs (Kogan, 1984).

The extent to which parents welcomed these extra powers, certainly at this time, is unclear. In fact, the more far-reaching proposals set out in the Green Paper were rejected. Hammond (1986, p.136) says, 'this rejection, coming as it did from some 4,000,000 parents, did much to change Sir Keith [Joseph's] mind'. Less radical proposals were set out in the subsequent White paper, Better Schools (DES, 1985), in which parents formed the largest group, though not the majority on the board. But if government wanted to use parents as a means to push forward their own agenda they may have been disappointed. In an empirical study Pascal (1988) investigated the role of parents as school governors over a 3-year period between 1981 and 1984 in a sample of Birmingham primary schools. Pascal reports that parents saw their role as largely 'procedural', providing support for the school, with little involvement in matters of curriculum or what Elliott (1977) would call 'social accountability', still seen as the preserve of the profession. Though most parents felt they made a positive contribution, Pascal $(1988$, p.20) concludes that boards 'are struggling to make any real impact'.

Why was the profession apparently ready to accept these changes to their professional standing and relationships? Ginsburg et al (1988) examined the prevailing conditions under which these changes in relations between teachers and the State occurred over the period 1976 to 1981, commenting on the importance of 'events' in shaping outcomes. Key here was falling school rolls which increased competition between schools and threatened jobs:

Given the consequences of this for reduction in staff, teachers seemed to opt for being held accountable rather than trying to maintain authority and risk the threat of redeployment or total job loss. (Ginsburg et al, 1988, p.331)

Where teachers mobilised this was in response to jobs rather than changes to professional standing or conditions of employment.

\section{Changes to the curriculum}

The white paper Better schools (DES, 1985) (which formed the basis of the 1986 Education Act) formally set out the government's intentions to take control over what was to be 
taught in schools, employing the traditional policy tactic of reference to 'widespread' (though unspecified) agreement:

Consultations with the Government's partners in the education service and with other interests have shown that there is widespread acceptance of the need to improve the standards achieved by pupils, and of the proposition that broad agreement about the objectives and content of the school curriculum is a necessary step towards that improvement. (p.9)

The argument for a national curriculum was ostensibly centred around the need to raise standards by a return to a traditional subject focus and to meet the needs of industry. These moves towards centralised control of the curriculum had been coming a long time, Jim Callaghan himself having referred to it in the Great Debate in 1976. Bennett $(1984$, p.158) reports that 'shadows' were already visible in the 1981 policy document The School Curriculum (DES, 1981) and goes on, 'but it has now been outlined clearly [by] the Secretary of State... with the promise that colouring in will start this autumn'. Bennett comments on the regressive nature of these reforms by quoting the Hadow Report of 1931 which had stated that:

the curriculum is to be thought of in terms of activity and experience rather than of knowledge to be acquired and facts to be stored. (Board of Education, 1931, p.93) Although the 1986 Act set in motion the events which tightened central control over what was to be taught in schools it was the Great Education Reform Bill (or 'GERBILL', as it was waggishly known) and the subsequent Education Reform Act (more prosaically the 'ERA') (1988) which consolidated these moves (DES, 1988). Thus, Bennett (1984, p.158) displays considerable prescience in his comment that:

It appears that the education service which takes us into the 1990 s will be organised on a centre-periphery model. The DES will lay out national statements of achievement targets and learning goals, cast in terms of core subjects (English, mathematics, science, foreign languages)...Within this core, as well as elsewhere, this framework is intended to include specific objectives for each subject. However, this national framework is not intended to tell teachers how to teach...Schools then are required to set their own aims and objectives, and monitor their achievement. 
The Bill proposed that testing (at 7,11,14 and 16) would, in non-examined subjects, largely rely on teacher assessments carried out 'as an integral part of normal classroom work' alongside prescribed tests (para 29.) Broadfoot (1987) questioned the feasibility of such an approach - in terms of both the construction of suitably valid and robust tests and the practicality of their administration - and concludes that given the attendant difficulties, the suspicion must be that 'the real purpose of the tests lies elsewhere. That at the heart of the proposals is not the accurate assessment of individual pupil achievement but the reinforcement of procedures for surveillance and control through a discourse of competition and accountability' (Broadfoot, 1987, p.17). Broadfoot accurately predicted the ensuing chaos as teachers attempted to carry out assessments as part of their 'normal' classroom activities (resulting in a move to reliance on norm-referenced benchmark testing, which Margaret Thatcher was known to favour). However, her prognosis that it is doubtful whether such a policy could be imposed indefinitely against concerted professional opposition and perhaps substantial parental disquiet as well' (p.17) has since proved wide of the mark.

As well as the introduction of a National Curriculum and objectives to be met at a number of 'key stages' the ERA also introduced a range of changes, mainly concerned with devolved financial arrangements, which further undermined the role of LEAs (and the Act took the opportunity to abolish the troublesome Inner London Education Authority). Most significantly these were: the local management of schools (LMS) which devolved budgets, using a per capita funding formula, to schools under the control of the headteacher and board of governors (similar legislation was extended to Scotland); grant maintained (GM) schools, funded directly by central government (determined by parental ballot); and city technology colleges (CTCs), focusing on vocational skills and 'sponsored' by businesses (widely reported as modelled on US 'magnet schools'). The Assisted Places Scheme, enabling academically selected pupils to attend independent schools was expanded and both GM schools and CTCs were allowed to select a proportion of students based on 'aptitude and ability'. All these measures were intended to extend the market-place for education by offering choice, not just of school, but of type of education provided, and to reduce the power of the LEAs, thereby consolidating the changes to governance of the 
system. In this way specialisation, casuistically, provided cover for a return to greater selectivity.

If, in the earlier part of the decade, MacBeth (1984, p.170) had been right to comment that 'the Scottish system is marginally more centralist (in regard to curriculum control, finance and the Inspectorate) than is the English', this was certainly no longer the case by the end of the 1980s and into the 1990s. Although Scotland introduced the 5-14 Curriculum (SOED, 1994) this was not statutory but 'national guidelines' (though it would be a brave headteacher who did not accept this guidance) and did not cover the senior phase of schooling. Unlike standardised national testing that accompanied the National Curriculum in England, the 5-14 curriculum included testing at a number of levels but only when the teacher judged the child to be 'ready'. Children sat five levels of tests (A-E) administered by the class teacher, the results of which were widely dismissed as unreliable.

\section{The 1980s: a summary}

Stephen Ball (1997) criticises those researchers who tend to see 1988 as 'ground zero' in terms of educational policy research. Though he is right to do so, one can see why it happened - from the major legislation set out in the UK 1944 act, establishing the modern post-war educational system, until 1988 the broad brush of historical hindsight might conclude that very little changed. Though this is far from the truth in one respect the 1988 Act did represent ground zero: the radical change of direction put a determined full stop to the 'post-war consensus' which had assumed a gradual and irreversible move towards progressive socialism. By the end of the 1980s a set of far-reaching changes profoundly changed the shape of the education system, establishing a quasi-market based on choice and accountability. As Salter and Tapper (1981, p.49) remarked early on in the decade, 'we may be witnessing something of a contradiction in terms - a state sponsored attempt at revolutionary change'.

It is worth pointing out, however, that the situation was rather different in Scotland. A belief in the greater egalitarian nature of Scottish society and an 'anti-Thatcher rhetoric' (Arnott and Menter, 2007) coupled with greater confidence in the education system, ensured that moves towards the market were more muted. Confidence in non-selective secondary 
schools and in the professionalism of teachers remained high and only two schools opted out of LA control. This is not to say that the education system in Scotland remained immune from the shift to neoliberalism, but that this manifested differently and Scotland's education system, already distinct, continued to diverge from the other UK polities into the 1990s and beyond.

\section{The Major years 1990-1997: the turn to (educational) governance}

In 1990 Margaret Thatcher was ousted and replaced by John Major who, against all the odds, won the 1992 general election and remained PM until 1997. Although the style of leadership was very different, the overall trajectory remained largely unchanged. It was during this decade that the effects of the ERA came to fruition. The apparently paradoxical mix of centralising and decentralising measures referred to by Ranson (1986) in analysing the 1980 Act was finally named in educational discourse as 'governance' by Stephen Ball drawing on the etymology of 'steering' (Kickert, 1991):

Steering at a distance is an alternative to coercive/prescriptive control. Constraints are replaced by incentives. Prescription is replaced by ex-post accountability based upon quality or outcome assessments. Coercion is replaced by self-steering - the appearance of autonomy. Opposition or resistance are side-stepped, displaced. (Ball, 1993, p.111)

This 'new paradigm of governance' (Ball, 1993), arguably initiated in the 1980s in all but name, finally established a bridgehead in the educational research literature in the 1990s. Ball set this within a conceptual framework of performativity as 'a more subtle yet more totalising form of control of teachers' (p.111). Although Ball was not the first to draw on Foucauldian notions of the technology of the self (see, for example, Broadfoot,1987) he was undoubtedly instrumental in opening this up as a most uberous line in educational research in the 1990s and into the new millennium.

The ERA provided educational researchers with fertile ground for empirical work and comment (most of it critical) around devolved budgets, grant maintained schools, city technology colleges and the marginalisation of LEAs. The notion of the ideology of the 
market is a common theme in these papers, an indicative sample of which is presented below. It should be noted that the conclusions drawn by these authors may be contested, they are presented here without critical comment to show how discourse at this time was being constructed by educational researchers.

Power et al (1994) examined whether GM schools were realising the aim of diversifying educational provision and expanding parental choice. GM schools were promoted by government as a means by which parents could 'escape the policies of Labour controlled LEAs' (p.210) and the authors quote the Centre for Policy Studies as saying 'many...feel that their children are trapped in schools...[which] are being used for the promotion of secular and socialist values' (Centre for Policy Studies,1988, p. 10, quoted in Power et al, 1994, p.210). By side lining the LEA schools, it was argued, would be free to promote their own values. For critics the fear was that GM schools would lead to a 'two tier' system. Power et al quote Jack Straw (then Shadow Education Minister) as saying that the intention of GM schools was to undermine comprehensive education and bring about a return to selection However, Power et al conclude that the impact of GM schools seems to have been minimal:

So far, there is not much to indicate that GM status, by itself, is having any significant impact on patterns of school choice. It marks neither a widening of choice, nor a highly desired alternative. There is evidence, however, that the conjuncture of GM status and selective schooling alters the ability of parents to obtain a place at the school of their choice...GM status has on the whole frustrated the realisation of choice. (p.223)

Similarly, Deem et al (1994) conducted a study of school governors in the context of LMS arguing that the market ideology caused schools 'to turn inwards on themselves...examining their image and market appeal [in order to attract the] desirable middle class parent and child' (p.548). This, they argued, resulted in greater uniformity of school provision. Moreover, the scramble for these 'desirable' pupils, they claim, effectively reduced choice 'for working-class and ethnic minority, parents and pupils' (p.535). Thus, the aim of the ERA to enhance diversity and choice actually resulted in the converse: GM and LMS schools tended to stay as they had been or, in the pursuit of the 'right pupils' aimed for conformity, and thus real choice in a diverse market-place did not materialise (on the other hand neither were the fears that GM schools would be a backdoor return to grammar schools). 
Vincent et al (1994) report a study of the effect of LMS on the provision of special educational needs (SEN). The legislative framework for SEN provision had been set out in the 1981 Education Act, which largely followed the recommendations of the much respected (at the time) Warnock Report (DES, 1978) which abolished categories of disability, and supported the concept of integration of children with SEN in mainstream schools. The Warnock Report asserted that around $20 \%$ of pupils could be considered to have SEN, of whom 2\% would require a 'statement' (in Scotland a 'Record of needs') and specialised support, to be provided by LEAs. Thus, the legislation had been in place for some time before the impact of the ERA was felt. The study examined the responses of two LEAs, each with its distinctive 'culture, history and ethos' (p.265) as they worked to negotiate the changes required by the legislation in the light of devolved school budgets. While noting that the legislation does not promote a 'wholly free market' (pointing to the retention of power at the centre), the authors argue that the discourse of the market is pervasive, leading to 'values drift'; and they question whether children with SEN might be 'weaker players in the market-place' (Vincent et al, 1994, p.264). Though the authors are very critical of the outcomes of these changes (especially in relation to the 'atomisation' of services) one interesting factor emerged as an unanticipated consequence of the Act: in forcing schools to overcome their 'learned ignorance' (p.271) and accept their responsibilities in relation to the $18 \%$ of pupils with SEN but no statement, moves towards greater inclusion of these pupils was promoted. In addition, though the ERA further marginalised local authorities they proved to be critical to its implementation; and though their actions were necessarily constrained by the legislation their differing responses indicate that they were not without weight as actors in the policy network. Similarly, in the implementation of the government's plans to open CTCs local authorities exerted considerable influence. In all only 15 CTCs were ever built, one of the main problems being the difficulty of securing suitable sites in inner cities areas, attempts at which were frequently frustrated by local authorities (Dale, 1989; Walford, 2000).

Evans and Penney (1994, p.520) start from the premise that 'the whole object of ERA reforms has been to change the system of educational governance in England and Wales from one where control is exercised by the LEAs to one where market forces reign supreme'. They report on the effects of these changes on an advisory and support service 
offered by one LEA to schools. With LEAs marginalised under a series of Education Acts, most notably with budgets for support services being devolved to schools under LMS and the elevation of monitoring and inspection over advice, the future of this service looked 'particularly bleak' (p.529). The position of the LEA was further jeopardised by the 1992 Schools Act which reconfigured HMI (Her Majesty's Inspectorate) as the Office for Standards in Education (Ofsted). Ofsted was established as an 'independent' inspection service awarding contracts on a competitive basis, thereby extending market ideals into the inspection process. However, 'much to the chagrin of the political new right' (p.529) 90\% of inspection contracts went to LEAs, including the LEA in Evans and Penney's study. Moreover, this injection enabled the LEA to expand the support side of its work, developing services for schools. Thus, the moves intended to side line the LEA were undermined by the very office set up by government to do this.

Typically, educational research was highly critical of the ERA and the market ideology promulgated within it. Yet, examining these cases it could be argued that the effects of the ERA were not entirely as anticipated. Why was this? Jonathan (1990) points to the incongruity inherent in the ideology of the 'New Right', and manifest in the ERA, between libertarianism and conservativism:

The first of these elements embodies an endorsement of competitive individualism and implies a reduced role for the state, with the market determining the production and distribution of goods - public as well as private, social as well as material...The second, conservative, element requires, on the contrary that the state be sufficiently strong to maintain property relations and related rights in the situation of unequal distribution which is logically required for competition to flourish. (Jonathan, 1990, p.17)

The juxtaposition of these incongruities creates a dialectical tension which emerges in the implementation of the ERA and may be considered responsible for the subversion of the aims of the legislation. Although dialectic has no clear and unambiguous meaning Schneider (1971, p.667) identifies a number of 'meaning clusters' that are relevant for social scientists, including: unanticipated consequences; adaptations that once made obstruct more effective ones; contradiction, paradox and negation; goal shifts; and the dissolution of conflict in the coalescence of opposites, from which list it can be seen that the reflexive moment of 
reversal inherent in dialectic is an essentially ironic movement. Each of the subversions in the empirical studies outlined above embodies an aspect of this dialectical irony.

The same dialectical tension inhabits 'governance' itself. As noted earlier, Lobel (2012) characterises 'the new governance' as a response to the failure of both top down command and control government and unregulated markets. This gives rise to the apparently contradictory mix of centralising and decentralising policies that effectively constitute 'steering at a distance'. In establishing governance as a new political theory, Rhodes (1996, p.660; original emphasis) defined 'Anglo-governance' as referring to 'self-organizing, interorganizational networks' incorporating a range of policy actors from private, public and voluntary sectors and argues that:

Networks are not accountable to the state; they are self-organising. Although the state does not occupy a privileged, sovereign position, it can directly and imperfectly steer networks.

Rhodes argues that the growth of networks decentres and diminishes the state and quotes Kickert (1993) in saying that as a result of this 'Government does not have enough power to exert its will on other actors'. This is the 'hollowing out of the state' thesis (Peters, 1994). ${ }^{6}$ As Rhodes (1996, p.662) notes, 'steering complex sets of organizations is difficult'. But it is not just that it is hard to do, steering at a distance embodies a paradoxical conjunction of hierarchy, markets and networks. Given this dialectical tension, the opportunity for ironic reversals of all kinds is inescapable. Indeed, Hogwood (1997, p.708) comments that: 'One of the ironies of the Conservative government has been that, in its concern to roll back the frontiers of state (to say nothing of the constant theme of de-regulation), it has presided over the greatest extension of formal regulation of any postwar government'. In fact, other commentators, have rebutted the 'hollowing out' thesis, arguing that far from a hollowing out there has been a 'filling in' (Taylor, 2000) - or rather, in another ironic move, the hollow core of the governance network is occupied by government.

\section{The 1990s: a summary}


It is in the educational research literature of the 1990s that the turn to governance is evident. A shift in usage from governance as 'school governance' (the functioning of boards) to its re-conceptualisation as the development of regulatory strategies by the State of complex educational systems emerges: the language of 'steering' becomes common, as does the concept of the network. Yet it is also evident that steering of increasingly fragmented systems allows considerable room for the subversion and undermining of the command structures at the centre. Thus, many of the provisions of the ERA failed to achieve what they set out to (Pierson, 1998). Yet, under successive Conservative Governments the introduction of a market ideology, flawed as it was, led to fundamental changes in governance which were sustained and arguably strengthened by the incoming New Labour administration, leading to a widespread belief in the 'naturalisation' of neoliberalism (Peck and Tickell, 2002).

\section{New Labour 1997-2010: partnership and performativity}

The 1997 election was won by the Labour party (led by Tony Blair, PM from 1997-2007), now dubbed 'New Labour' to dissociate itself from the entryist 'Militant Tendency' that had attempted to subvert the party from within in the previous decade. The foundations of governance had been laid down in the moves to neoliberalism ${ }^{7}$ by successive Conservative governments. How, and to what extent, was this continued by the incoming Blair administration? Certainly, the commitment to markets was maintained. Davies (2005, p.316) quotes Blair as saying: 'the best way to promote efficiency in production is through competition, liberalization and open markets'. But there was a shift in tone. For Blair the market could be harnessed towards meeting social objectives: 'entrepreneurial zeal' Blair said, 'can promote social justice' (Davies, 2005, p.316). This was the idea that lay at the heart of the 'Third Way', the term Blair adopted to distinguish New Labour's ideological stance of centre right economics and centre left social policy, both from previous Labour governments and the outgoing Conservative administration. Powell $(2000$, p.51) quotes the Department of Social Security policy document New Ambitions for Our Country (DSS, 1998, p. 19), as saying the Third Way 'is about combining public and private provision in a new partnership for the new age'. Indeed, 'partnership' was the watchword, underpinning a commitment to multi-level governance, part of an integrated process providing, as Blair was fond of saying, 'joined up solutions to joined up problems'(Taylor, 2000, p.56). Although 
educational research tends to situate Third Way-ism as an essentially UK phenomenon, Johnson and Tonkiss (2002) argue that it had important antecedents in Australian governments of 1983-1996. Third-Wayism thus provides an early example of 'travelling policy', a concept in educational policy research which gathered pace through the 2000s and into the 2010s as interest in the global nature of educational governance increased.

The New Labour government introduced a wide range of measures aimed at promoting participation and collaboration between diverse stakeholders (Davies, 2005). Yet the accumulation of regulatory powers to central government continued as further evidence of the 'filling in of the state' (Taylor, 2000). Stoker (2002) refers to New Labour's approach as 'governance by lottery', in which 'winners and losers are selected by chance but in which no one has come up with the big prize' (p.418). Further, Stoker argues that this was not about 'unintended consequences undermining grand reforms', but a deliberate strategy arising as a direct result of the 'what works' pragmatism inhabiting the Third Way, and as a means by which to manage the tensions within it. Stoker points to a plethora of initiatives resulting in a 'Byzantine structure of plans, zones, and separate financial pots (Stoker, 2002, p.424). Harris and Ranson (2005) list among these Excellence in Cities (EiCs), Schools Facing Challenging Circumstances (SFCC) and Educational Action Zones (EAZs), all of which required the formation of partnerships between the public and private sectors. Similarly, Powell (2000, p.57) refers to the Third Way as a 'pick and mix strategy, largely defined by what it is not' and he draws on Marx's famous dictum that history repeats itself, the first time as tragedy and the second time as farce. It is worth quoting Marx (correctly) in order to appreciate the appositeness of Powell's observation:

Hegel remarks somewhere that all great world-historic facts and personages appear, so to speak, twice. He forgot to add: the first time as tragedy, the second time as farce...Men make their own history, but they do not make it as they please; they do not make it under self-selected circumstances, but under circumstances existing already, given and transmitted from the past. (Marx, 1852, np)

If 'governance' under the Conservative neoliberal regime had negotiated a tension between hierarchy and markets, Third Way neoliberalism manifested a certain element of 'paranoia' 
in its simultaneous strategies of 'hierarchical control and egalitarian partnership' (Stoker, 2002). Stoker goes on, 'That both strategies are tried and directed at certain groups reflects New Labour's deep fatalistic streak and uncertainty about which strategy will work' (Stoker, 2002, p.432). Viewed in this light the Third Way starts to take on a distinctly Kafkaesque hue.

Education was at the sharp end of much of this conjunction of 'hierarchical control and egalitarian partnership'. During the election campaign, Labour Party leader, Tony Blair famously declared that his three priorities were 'education, education, education' ${ }^{8}$ Education was seen to be the main route by which social justice could be achieved, following the precepts of the 'school effectiveness movement' it was believed that schools could make a difference - and hence should be held accountable for performance (see Chitty, 1997b, for a critique). If some may have hoped that an incoming Labour government might undo much of the previous administration's legislation, they were to be disappointed, if not in the detail at least in the overall direction of travel. The White Paper Excellence in Schools (Department for Education and Employment, 1997) set out the Government's position on education, subsequently enacted as the 1998 School Standards and Frameworks Act. The focus was to be on 'standards not structures' and there would be 'zero tolerance of underperformance' (p.5); literacy and numeracy hours were introduced and for the first time teachers would be told how, as well as what, to teach; 'Performance data' would be published 'as a spur to improve performance' for the benefit of parents; and, the government promised, 'We will publish more such data than ever before' (p.25). For the first time too, league tables would include a measure of the 'value added' to pupil achievement by the school, and 'benchmark data' would allow comparison with other schools (p.25).

Performance and partnership underpinned New Labour's programme of 'modernisation'modernisation in this context meaning the extension of hierarchical controls (Tomlinson, 2003). Modernisation was aimed at improving the performance of LEAs, teachers and the curriculum. LEAs had been marginalised by successive Conservative governments and under New Labour their role was further circumscribed. LEAs were closely directed by central government and their actions became subject to inspection. Tomlinson (2003, p.200) quotes 
a speech made by Tony Blair in 1998 in which he warns, 'If you [local government] are unwilling to work to the modern agenda, then government will look for other partners'. Modernisation of the teaching profession included performance related pay and the introduction of national competence standards; while modernisation of the curriculum included a narrowing of subject areas, more testing, and a greater focus on literacy and numeracy.

On the other hand modernisation of partnership included the 'redesign' of the public as 'active users who influence service design and planning' (Ozga, 2002, p.332), alongside a redefined role for business. Ozga points to social capital (SC) theory as underpinning many of the policies framing the partnership agenda. Social capital theory, as an academic construct concerned with networks and norms of reciprocity, enjoyed immense popularity in the latter half of the 1990s and into the 2000s but it was also 'one of the most popular exports from sociological theory into everyday language' (Portes, 1998, p.2). Thus,

Social capital theory acts as a powerful connecting device that links new forms of governance preoccupied with the measurement and improvement of performance to the constitution of society as a governable domain. (Ozga, 2002, p.333)

In this way governance itself was to be modernised, creating a new fusion between public and private (Ozga, 2002). Nowhere was this more evident than in the setting up of EAZs, intended to increase the SC of families living in disadvantaged areas. Are EAZs, Power and Whitty (1999, p.542) ask, 'the Third Way in action?'

EAZs were a prime example of Stoker's (2002) 'governance by lottery'. Partnerships, which could include schools, the LEA, local and national businesses, the training and enterprise council, religious bodies, voluntary and community organisations, and other local government agencies (DfEE, 1997), could bid competitively for EAZ status and were funded to the tune of $f 500-f 750 \mathrm{k}$ per annum (Gewirtz et al, 2005). EAZs typically consisted of around 20 local primary and secondary schools and their associated partners, headed by an EA Forum (EAF) intended to enable non-professionals to assume key roles in leading change (Ozga, 2002). Ozga quotes the DfEE who argued that EAZs would work precisely because 
they would bring 'new skills, experience, funding and radical ways of working with educators' (DfEE, 1997; quoted in Ozga, 2002, p.337).

EAZs were heralded at the outset as a 'flagship' policy. Gewirtz et al $(2005$, p. 328) quote influential New Labour politician, Margaret Hodge, as saying, 'the development of the Third Way is perhaps best seen in the development of education action zones'. It was a relatively short-lived scheme, however. Announced in 1998, 25 EAZs were set up in 1998/9; 48 more followed in the next two years, but by 2005 all (statutory) EAZs had been incorporated into the next (non-statutory) initiative, 'Excellence in Cities'. What were the reasons for the relative failure of this emblematic policy? Power and Whitty wrote presciently in 1999, that 'the new "synergy" between public and private may bring additional resources to zones but it may also bring together a variety of agendas that are far from complementary' (Power and Whitty, 1999, p.544), and this proved to be the case. EAZs arguably collapsed under the weight of their own internal dialectical tensions. In the normative discourse of partnership the presence of conflict is under-recognised and certainly under-theorised: Davies (2004) writes that dominant patterns observed in partnerships are hierarchical and agonistic rather than coordinating. By unpicking the constituent elements in an empirical study of three EAZs, Jones and Bird (2000) highlight the delicate balancing act entered into by public/private partnerships and the competing tensions this gives rise to. They describe a 'tangled unevenly resourced complex of interests' for which the term 'partnership' 'does not seem to describe the processes that result' (Jones and Bird, 2000, p.504).

Gewirtz et al (2005) draw on social capital theory to explain the failure of EAZs to achieve their aims. They conclude that many of the schemes failed to engage with the parents and families they were set up to help. Certainly, EAFs did not reflect the composition of the communities they represented, and, being largely composed of white, male professionals served to enhance the SC of the 'already network rich' (p.659). Moreover, the strong bonding SC that existed within local working class communities, Gewirtz et al argue, worked actively against the cultivation of other forms of SC, notably bridging and linking SC. Bonding SC creates strong ties within groups but can be an exclusionary force. Bridging and linking SC are weaker forces but serve to connect groups outwards and upwards respectively: 
Although bridging and linking ties are weaker in the sense that they are likely to be less intimate than bonding ties, they provide access to valued forms of economic and cultural capital - a paradox capture in Granovetter's (1973) phrase 'the strength of weak ties'. (Gewirtz et al, 2005, p.668)

Not all weak ties are strong, however. Davies (2004) also draws on Granovetter's term in attempting to understand why the 'constant flow of urban policy initiatives to promote collaboration have not generated strong institutions based on informal modes of constraint' (p.570). Davies points to the 'endogenous tensions' that lead to dysfunctionality and selfdestruction. Partnerships are frequently hierarchical in nature and characterised by 'weakweak' ties between actors which do not provide effective bridges. Thus, while a logic of collaboration was evident among the political elites it was less strongly replicated in the business community.

As with the measures introduced by the ERA, New Labour's EAZs largely failed to achieve their ends. Research indicates too the failure of Labour's Academies (schools independent of local authority control and usually sponsored by business) to achieve their goals of 'breaking the cycle' of underachievement in socially and economically deprived areas (Office of the Deputy Prime Minister, 2004). Though at the outset government claimed significant improvement in attainment over a very short period for this initiative, analysis by Gorard (2005) indicates that where exam results had improved this could be almost entirely attributed to subtle changes in pupil intake that had resulted as an unanticipated outcome of policy. Gorard refers to this as 'sleight of hand school improvement' (p.376).

\section{Performance}

If partnership was emblematic of the Third Way, it seems that this was just a distraction from the main event. Gewirtz et al $(2004$, p.328) quote a civil servant who claimed that EAZs were 'simply one of a number of initiatives the government was trying out' while the 'core agenda' was performance (though this may have been putting an acceptable spin on the failure of EAZs post hoc). If partnership could be said to be concerned with structure, performance was squarely about standards, effectively inaugurating what Stephen Ball 
(2000) referred to as 'the performativity society' (a clear manifestation of the paranoia Stoker was referring to):

Performativity is a technology, a culture and mode of regulation, or a system of 'terror' in Lyotard's words, that employs judgements, comparisons and displays as means of control, attrition and change. (Ball, 2000, p.1)

New Labour's focus on standards and performance proved fruitful ground for educational researchers and common themes emerged in the literature drawing on Foucauldian notions of 'technologies of the self'. Performativity thus implies an 'internalised disposition' of accountability, in which 'routines of performance surveillance bite deeply into the attitudes, practices, and identities of state professionals' (Ranson, 2003, p.469). Thus, under New Labour there was an intensification of neoliberal regimes of governance, as grotesque parody (echoing Marx's dictum), in comparison with which previous Conservative administrations end up looking quite amateur.

Gleeson and Gunter (2001) comment on the shift in New Labour's approach from external to internal accountability. They argue that the ERA (1988) failed to achieve its objectives due to the lack of a policy mechanism to deliver 'its oppressive mix of prescription, tests and inspection' (p.147). New Labour, by contrast, instigated different mechanisms of performance management to deliver its own oppressive mix. Among the policies introduced by New Labour to increase internal accountability was 'Threshold Assessment' (TA), set out in the Green Paper, Teachers meeting the challenge of change (DfEE, 1998). This paper outlined a number of initiatives aimed at raising teacher performance but none was more contentious than TA. TA was a system of annual appraisal linked to a pay policy that rewarded 'good performance' (Mahony et al, 2004):

From induction up to Threshold, teachers progress by yearly increment. Threshold is highly significant as the point at which, normally after five years, teachers submit themselves to an assessment process...If teachers meet the Threshold standards they receive, in the form of a performance related promotion, an additional $£ 2000$ pa and transfer to an upper pay spine (UPS). (Mahony et al, 2004, p.445) 
Gleeson and Gunter (2001) argue that this acted as more than mere incentivisation of the teaching profession. Rather, policy was aimed at the creation of new professional subjectivities through the internalisation of measurable performance standards. It represented, in Stephen Ball's (2003) memorable phrase, 'the struggle over the teacher's soul' - the apotheosis of 'steering at a distance'.

Mahony et al (2004) carried out empirical research with teachers subjected to TA. While three of their participants viewed TA as a positive experience of professional development the remaining 42 did not, though many complied with its terms. Mahony et al (2004, p.461) conclude that TA 'carries a clear danger that other elements of what is educationally important will either be regarded as marginal or felt to be in conflict with teachers' personal and professional values'. To this extent, the re-shaping of professional subjectivities may be said to embody a degree of what Ball (2000) refers to as 'fabrication' as an 'accommodation towards performativity' (p.5):

There is a splitting between the teachers own judgements about 'good practice' and students 'needs' on the one hand and the rigours of performance on the other. (Ball, 2000, p.6; original emphasis)

Once again, however, the situation was rather different in Scotland. During the New Labour era Scotland (and to a lesser extent Wales) became devolved polities. ${ }^{9}$ UK governance relationships were significantly altered and educational policy continued to diverge in Scotland. A key difference in the approach taken in Scotland arose through the report of the McCrone committee (SEED, 2001). In contrast to England, the McCrone settlement included a big upfront pay increase for teachers, a 35-hour working week, and a cut in class contact time (with the freedom to undertake duties outwith the classroom at a time and place of the teacher's choosing). A Masters-level 'Chartered teacher' qualification, was introduced which any teacher at the top of the main salary scale could undertake and which led to entry to a higher pay scale. Significantly, Chartered teacher status did not carry any additional statutory duties or responsibilities.

The 'McCrone agreement' needs to be seen in the context of its historical antecedents, which included unrest in the profession over workload issues and concerns over the supply and retention of teachers (Draper and Sharp, 2006). There was also a concern that the 
profession had suffered as a result of increases in centralisation and a reduction in professional autonomy and the report was therefore concerned to 'restore' teacher professionalism. Ironically, perhaps, it did this through contractually obliging teachers to undertake 35 hours of continuing professional development (CPD) per annum. Though teachers welcomed the pay increase (around 10\% for most) others of its changes (particularly CPD and Chartered Teacher status) proved divisive.

More recently (though I am getting a bit ahead of myself here, encroaching on the 2010s), the influential policy document Teaching Scotland's future (Donaldson, 2010) and the follow up document, Advancing professionalism in teaching (Scottish Government, 2011, 'McCormac Review'), have sought to re-narrativise McCrone as having done harm to the professionalism of teachers (and little to enhance the learning of pupils). Both reports call for a change in the nature of teacher professionalism. Donaldson talks of 'enhanced professionalism' the 'extended professional' and 'twenty-first century professionalism' - a professionalism that goes above and beyond and is not contractually based. In the light of this, the General Teaching Council for Scotland (GTCS) has assiduously recast teacher professional development - or what it now calls 'professional learning' - as a teacher's right, rather than an obligation (Watson and Michael, 2016). Indeed, the appraisal process, in Scotland called 'Professional Review and Development' (PRD) carried out against a suite of professional standards, ${ }^{10}$ is determinedly developmental:

Where it operates successfully, professional review and development (PRD), is understood as an entitlement of all teachers which assists them to reflect on their practice and to consider how they can improve their professional skills and knowledge. (GTCS, nd; emphasis added).

However, recognising that the implementation of PRD has been undeniably patchy it was announced by the Scottish Government, in 2012, that teachers would henceforth be required to maintain 'active registration' with the GTCS through a process of 'reaccreditation' (rapidly renamed 'Professional Update' by the GTCS). Under this process, every person registered with the GTCS must undergo professional update (PU) every five years in order to remain on the register of the GTCS and, therefore, licensed to practice. Surprisingly, perhaps, this too is largely seen as a supportive process rather than an 
unwarranted extension of managerialism (Watson and Fox, 2015). In this way, the cultivation of professional subjectivities has followed a rather different path in Scotland in which teachers view PRD and PU as part of a process of continual professional learning. Indeed, a study of early career teachers indicated the strong desire this group of teachers had to 'continuously develop themselves' following the precepts set out in the newly introduced GTCS Standard for Career Long Professional Learning (Watson and Drew, 2014).

It may be tempting to view the situation in Scotland through a rosy lens (especially from the vantage point of England) but this would be to misunderstand the extent and nature of managerialism which has clearly adopted a more Deleuzian form of control based on desire (as plenitude), in contrast to the overtly Foucauldian disciplinary route taken in England (Watson, 2010). Thus cultural differences shape responses to global forces in different ways.

\section{Summary of the 2000 s}

Power and Whitty $(1999$, p.542) cite Anthony Giddens in asserting that the Third Way, involves moving beyond the old dualism between state and civil society - in which government is either the solution or the problem, and accepting a new version of government which will renew civil society through increased democratization, greater transparency and experiments with democracy.

Yet, they also note that much of New Labour's educational policy was a continuation of the market ideology put in place by the previous Conservative governments, and they suggest that Michael Novak may be nearer the mark in his comment that, 'the triumph of Tony Blair may in one sense be regarded as the triumph of Margaret Thatcher' (Novak,1999, p.89). Thus neoliberalism continued to, forge ahead 'never arriving at its stated destination, and never knowing where to stop' (Peck, 2010, p.7). What also starts to become clear in reading the educational research literature of the 2000 s is the location of educational policy within a wider globalised context of neoliberal 'modernisation' as a result of the rise to prominence of the OECD and other transnational spaces of governance. This is explored further in the final section of this paper. 


\section{0s and the return to Conservatism: globalisation, digitisation and 'New spaces of governance'}

Despite the continuing reverberations of the 2008 Crash which caused severe economic shock around the globe, reports of the death of capitalism proved to be exaggerated. The incoming Conservative/Liberal Coalition government of 2010, led by David Cameron, took up where New Labour left off and in terms of educational policy Avis (2011) notes, that the continuities far exceeded the ruptures. Thus, Michael Gove, Education Secretary from 20102014, extended the Academies scheme of independently funded schools set up by New Labour (itself an extension of the old Conservative CTCs), enabling fast track measures that could circumvent usual local democratic procedures. With apparently no irony, John Bangs, head of education at the National Union of Teachers, is reported as saying in the Guardian newspaper, 'This is astonishing: it is more centralised than anything that Labour ever considered' (Shepherd, 2010, np). Gove also announced a programme of 'Free schools' (State schools independent of LA control, modelled on US Charter schools), set up where there was parental demand which the DfE (2010) claimed would 'enable excellent teachers to create schools to improve standards for all children'. Gove was, in Gillard's (2016) words, 'a man in a hurry'. In explaining the urgency of his task, Gove said in a speech:

For all the well-intentioned efforts of past governments, we are still falling further behind the best-performing school systems in the world. In Shanghai and Singapore, South Korea and Hong Kong - indeed even in Taiwan and Vietnam - children are learning more and performing better with every year that passes, leaving our children behind in the global race. (Adams,2013, np)

With this remark Gove encapsulated the globally competitive nature of education, within a discourse mediated by the OECD and other transnational organisations. Undoubtedly, the most influential of these supranational organisations is the OECD. The OECD was formed in 1961 as a club of rich nations of the global North (Sellar and Lingard, 2013). The mission of the OECD is,'to promote policies that will improve the economic and social well-being of people around the world' (OECD, nd). In commenting on this Rizvi and Lingard (2006) note a tension between a market-led orientation originating in the US and a social orientation influenced by Europe, but observe that in the current decade neoliberal precepts have 'triumphed'. 
With hindsight, it is possible to see the influence of the OECD in educational policy extending back several decades, though this did not feature to any great extent in the research literature. In particular, the 1970s saw moves towards the development of a set of 'educational indicators' designed to enable international comparisons and to elucidate causal relationships between social/cultural factors and economic progress (Olkinuora, 1973).This project has continued and the results published annually (since 1992) in the OECD's Education at a glance. Although designed to give information at the level of the nation state, the OECD now recognises that sub-national data are useful to government and institutions and hence the 2017 issue says (OECD, 2017, p.14):

There is increasing recognition that many important features of the development, functioning and impact of education systems can only be assessed through an understanding of learning outcomes and their relationships to inputs and processes at the level of individuals and institutions. To account for this, the indicator framework distinguishes between a macro-level, two meso-levels and a micro-level of education systems. These relate to: the education system as a whole; the educational institutions and providers of educational services; the instructional setting and the learning environment within the institutions; [and] the individual participants in education and learning.

Although the indicators cover a range of factors (including the characteristics of school systems and a range of social/economic factors) it is the indicators related to learning outcomes that have grabbed the headlines. Most notably the international tests that constitute 'PISA' (Programme for International Student Assessment), the triennial educational survey used to determine student performance in maths, science and literacy in member countries and associated partners. This move by the OECD assured its importance in the global policy domain, helping to raise its status from think tank to policy actor (Rizvi and Lingard, 2006). The first round of PISA was carried out in 2000 and in 2002 education achieved the status of permanent Directorate for Education and Skills from which base its influence has spread. In 2005 Lingard et al argued that the OECD's global educational policy 
field was 'inchoate', in the current decade we can probably say it has pretty well achieved choateness.

While the purpose of the OECD is ostensibly to provide member and partner countries with the resources they need to make effective education policy decisions to meet economic and social welfare goals, the emergence of PISA has effectively enabled governments to use international comparison as a key instrument of governance in its own right. In particular, the mediocre standing of the UK in relation to 'emerging nations' has been used to construct a rhetoric of education in crisis and so to legitimate changes intended to reverse the UK's 'poor performance', as Gove's comment attests. Lawn and Grek (2012, p.7) write, 'today, when the future can no longer be organised through meaningful projects by government, numerical data becomes a useful substitute for ideas'. This is 'governing by numbers' (Ozga and Lingard, 2007).

This trend has been further intensified as a result of the development of PISA-based tests for schools, which have opened up local spaces to OECD influence, 'indigeniz[ing] global developments to the local, while also externalizing comparisons of performance' (Lewis et al, 2016, p.29). This enfolding of the local and the global, by-passing the nation state, has led to the development of more complex ontological conceptualisations of the spatialities of governance. While the OECD talks of 'multi level governance' (OECD, 2016) (a term which started to gain currency in the research literature in the 2000s), Lingard and Sellar (2014) go beyond a scalar conceptualisation and talk about the growth of topological spaces of governance and the 'powers of reach' of organisations such as the OECD across time and space. This leads to a radical reconceptualisation of possibilities for action around measurement and comparison thereby creating new connections, 'producing a space of commensurability that relates each system (or indeed school) to others' (Lewis et al, 2016, p.35). These complex virtual spaces of governance have very real effects on teachers' practices through the ways in which pupils are taken apart and re-assembled (in yet another irony, the 'child at the centre' becomes dispersed as a series of codes). In effect, pupils are becoming 'machine readable' (Williamson, 2016a) - and PISA-shaped.

Although PISA is the best known global education data system other policy instruments make use of the affordances provided by 'big data', enabling the emergence of digital spaces of governance. Key among these in the UK are the National Pupil Database (NPD) and 
Ofsted's 'School Data Dashboard' package. Since 2002, the NPD has collected data on the educational progress of pupils from early years to higher education. The NPD currently has information on around 7 million pupils, collecting information 'as traces of data that can be standardised, joined together and aggregated with a national population data-set' (Williamson, 2016a, p.129). Ofsted's 'School Data Dashboard' package provides schools with an analysis of performance based on inspection data. As a result of this, school inspection itself is being shaped by data collection techniques 'crafted through the technical expertise of data software developers whose very existence is hidden behind the apparently objective surfaces and interfaces of the data itself' (Williamson, 2016a, p.130). Thus global 'edubusinesses' are able to exert considerable influence in the field of educational governance. Hogan (2016) points to the increasing involvement of global companies, most notably Pearson, in the development and implementation of national testing regimes in countries such as Australia, USA and the UK. In this way edu-businesses are able, she warns, to 'shape education policy problems and determine their solution in ways that are commercially beneficial to themselves or shareholders' (Hogan, 2016, p.98).

Increasingly, these new spaces of governance are becoming insinuated into individual learners as 'learning analytics', based on performance in online learning systems, providing 'real time' feedback to learners. Thus, where Ozga and Lingard (2007) refer to 'governing by numbers', Williamson (2016b, p.45) argues we are witnessing moves to 'governing by algorithm':

While governing by numbers seeks to collect and analyse learners' performance data in order to cast a grid of statistical calculation and comparability over national education systems, governing by algorithm involves the deployment of advanced software technologies to 'know' and on that basis to forecast, predict and automate appropriate pedagogies to instruct the individual learner.

Wilson et al (2017) caution against practices which reduce individual learners to a set of metrics which purport to 'individualise' learning arguing that, conversely, such practices are reductive and influence learning and teaching in unknowable ways. This points to an urgent need to better understand the influence of these forms of 'micro level' governance through empirical research (Selwyn et al, 2015; Robert-Holmes and Bradbury, 2017). 
The complex shifts evident in educational governance reflect those in social policy systems more broadly as moves towards more heterarchical forms of governance lead to altered relationships between governments and civil society. This has entailed a growing privatisation of formerly national welfare systems and the rise of what has been termed 'philanthrocapitalism' as billionaires such as Bill Gates aim to 'privatise good' in addressing the major social and environmental challenges facing the planet (Bishop and Green, 2015, p. 544). The role of philanthrocapitalism is clearly evident in education in the UK (Olmedo, 2014). Thus 'Academy chains' of schools set up and owned by ostensibly philanthropic organisations are able to subvert the usual democratic processes thereby blurring lines of accountability (Wilkins, 2012). The philanthrogovernance of Academy chains is creating new and interesting relationships between schools and the state. While academies must operate within national policy, powerful actants are able to leverage influence over governments thus rendering the question of steering at a distance rather ambiguous - who, these days, is steering whom?

It should be noted, however, that this is a distinctly English concern. In other parts of the UK, most notably Scotland, the experimental dismantling of the education system has not occurred. Education has remained largely under the control of central government working in conjunction with LAs. A recent shakeup of governance has tended to consolidate this with the establishment of six Regional Improvement Collaboratives, comprising representatives of LAs and Education Scotland staff, led by a government appointed Regional Director with the aim of pursuing a 'relentless focus on improvement' (Scottish Government, 2017).

\section{Summary of the 2010s}

During the 2000s, but particularly the 2010s educational governance research has tended to focus on the global sphere and the growth of digital data giving rise to an era of 'test based accountability'. In this way the ontological conceptualisation of governance has undergone extensive remodelling from a largely linear system of hierarchy, to a scalar 'multi level' system, and hence to a topological model reaching out across space and time and involving transnational institutions and commercial edu-businesses. With these processes national governments can be both steered and by-passed simultaneously through the affordances provided by digital data. In this way the reach of governance has been extended and deeply interpolated into the realm of the individual. 
Higham (2014, p.417) quotes John Coles, former Director General of Schools at the DfE, as asking at a British Educational Leadership and Research Society (Blemas) seminar in London in 2013, 'who cares who runs schools?' In the 1970s the question had been 'who should control our schools?' (Glatter, 1976), thereby encapsulating the profound shift in educational governance that has occurred in this period. The consequences of all this we do not know, though it is a likely bet that many of these will be unintended.

\section{Conclusions}

Even a paper of this length cannot explore all events in detail, and hence this account is necessarily partial. But it was never the intention of this piece to give an exhaustive account. Rather its aim was to provide an historical examination of relations between governance and educational policy; and more broadly, to produce insights into processes of educational policy change.

Educational governance has here been represented as a trajectory from its beginnings in the accountability movement; to the development of a market for education; changes in regulatory controls and centre/periphery relations leading to 'steering at a distance'; the rise of partnership and networks; and the development of transformed and transformative ontologies of governance. Governance has thus developed from a set of externalised regulatory controls by which to hold others to account, to a complex mesh of external and internal mechanisms subtly (and not so subtly) steering institutions and individuals. What lessons can be drawn from this? In developing this metanarrative I have identified 'ground zero' as the accountability movement in the 1970s, and especially the triumph of a certain form of accountability, in a general way located in Halpin's (1979) 'being accountable' (rather than 'offering an account'), and in particular 'economic' (Elliott, 1979) or 'technocratic' (MacDonald 1978) accountability. Of course, that there is a beginning is a narrative conceit, any historical account starts in medias res, but nonetheless accountability within the context of the global embrace of neoliberalism offers a reasonable starting point. The growth of economic/technocratic accountability in the 1970s began a process which has altered the relationship between teachers and pupils such that pupils have become the instruments by which teachers and schools enact performativity. The shift towards a marketised education system in the 1980 s strengthened this commodification of pupils and further necessitated the measurement and the gathering of data which has continued and 
intensified since as we have moved from the realm of the nation state to transnational spaces of governance.

The key question for educationists in all this is what is the influence of such shifts in governance on educational practices? This is a question that cries out for a programme of rigorous empirical research. In the past decade educational systems have become spaces for the collection of data, governed by the invisible algorithms which shape data consumption and production (Williamson, 2016b) and this is having far-reaching effects on practices of teaching and learning. Indeed, there are indications (so far anecdotal) that teachers no longer see teaching as the inculcation of formal knowledge and skills, but instead as a series of manoeuvres by which to 'track and monitor' pupils (Watson, 2018). The datafication of education is likely to continue: already we see the emergence of research around 'neurosensing' devices which purport to monitor student cognitive activities directly (Williamson, 2017). In light of such developments it is timely to reflect on MacDonald's (1978) prescient warning of the 'tunnels to dystopia' promised by the growth of the accountability movement.

The anxieties aroused by this Brave New World scenario are perhaps best countered by the second, more comic, theme that has emerged from this historical romp: the revelation that policies fail while politics is the art of concealing this fact. This was exemplified here through the Conservative's Educational Reform Act (1988) and New Labour's educational action zones (Gewirtz et al, 2005). That policy fails to achieve its aims is not a particularly interesting or novel idea, perhaps. Jessop (2003, p.106) comments 'markets, states and governance all fail' - if only because there are so many more opportunities for things to go wrong than to go right. Jessop points to two kinds of governance failures: the failure of policy within a mode of governance, and the failure of the mode of governance itself. And he outlines three sources of this failure: first, the nature of capitalism and its dependence on the 'contradictory balance between marketised and non-marketised organisational forms' (p.105); second, the tensions arising from unequal and incommensurate partnerships; and third, incomplete knowledge of the situation to be governed. All three have been clearly revealed in this review of the research around educational governance. But as this paper has repeatedly shown, it is not just that governance fails but that the inherent dialectical tension within any mode of governance inevitably gives rise to a 
moment of ironic reversal from which emerges the unanticipated consequence. The unanticipated consequence has long been a concern among eminent thinkers (Merton, 1936, lists among these Machiavelli, Adam Smith, Karl Marx and Max Weber). A cynical eye might see in all this a grim humour as the manifestation of the Law of Irony - 'the concrete realisation of the absurd' (Amiel, 1905, np). The tendency towards the absurd is scarcely surprising when one considers that crisis and failure are what drive the globalised neoliberal project towards its idealised, yet unattainable destination (Peck, 2010). (In yet another ironic twist we call this 'progress'). In this way we come to the realisation that governance and neoliberalism are inextricably entwined and so 'the failure-governance waltz keeps on playing' (Malpas and Wickham, 1995, p.43), leaving in its wake the bleached bones of once shiny policies.

\section{Notes}

${ }^{1}$ The 'Black papers' were a series of papers published in the Critical Quarterly Quarterly between 1968 and 1977. These articles were a right wing polemic against the comprehensive system and 'progressive' teaching methods. Among the contributors were Rhodes Boyson, Kingsley Amis and Iris Murdoch. See https://web.archive.org/web/20070929022136/http://www.criticalquarterly.com/history.as $\underline{p}$.

${ }^{2}$ The Schools Council advised government on matters of assessment in secondary schools. It operated from 1964 to 1984 when it was abolished.

http://www.educationengland.org.uk/history/timeline.html

\footnotetext{
${ }^{3}$ Scotland had a similar cause celebre in the form of Robert ('RF') Mackenzie in 1974, headmaster of Summerhill Academy, Aberdeen, but in this case it was treated as an aberration rather than as symptomatic of a national malaise (Dale, 1981).
}

${ }^{4}$ If the 1960s has been characterised as the 'long decade' the 1970s can be thought of as the 'short decade' - in effect, the 1970s began with the oil crisis in 1973 and ended with the election of the Conservative Government in 1979. 
${ }^{5}$ Voucher schemes were only introduced for nursery education (1996 Nursery Education and Grant Maintained Schools Act). They were abolished by the incoming Blair government in 1998.

${ }^{6}$ Although first used by Peters (1994) to refer to the loss of legitimacy and authority of government...in the post-war era' (Marinetto, 2003, p.596), as Rhodes uses it it refers more specifically to the current era initiated by Margaret Thatcher in which as a result of a number of trends: privatisation, growth of agencies fulfilling services, transfer of powers to Europe, and reduction in 'discretion' of public servants through the NPM central Government has been diminshed (Hogwood, 1997, p.714).

${ }^{7}$ Interestingly, the term 'neoliberal' was not much used in the educational research literature until the Blair government was installed.

${ }^{8}$ First use of this was a speech made in 1996 McKnight, Glennerster and Lupton (2005) http://oxfordindex.oup.com/view/10.1332/policypress/9781861345783.003.0003

${ }^{9}$ In 1999 Scotland and Northern Ireland assumed executive and legislative responsibility for education. Wales assumed executive responsibility in 1999 and legislative responsibility in 2006 (West, 2015, p.32).

${ }^{10}$ The suite of Standards in Scotland currently comprises (though it is under review):

- Standards for Registration (which combines the Standard for Provisional Registration for those undertaking initial teacher education, and the Standard for Full Registration for newly qualified teachers. These Standards are mandatory). (GTCS 2012a)

- Standard for Career-Long Professional Learning (for those teachers who have achieved Full registration. This Standard is not mandatory). (GTCS 2012b)

- Standards for Leadership and Management (for those in or aspiring to middle leadership and headship, for which it will become a requirement).

(GTCS 2012c) 


\section{References}

Adams, R. (2013). Michael Gove stands by school reforms. Guardian, (3.12.2013) https://www.theguardian.com/politics/2013/dec/03/gove-defends-education-reforms [Accessed: 12.01.2018]

Amiel, H. (1905). Amiel's journal. http://www.gutenberg.org/files/8545/8545-h/8545-h.htm [Accessed: 12.01.2018]

Arnott, M., \& Menter, I. (2007). The same but different? post-devolution regulation and control in education in Scotland and England. European Educational Research Journal, 6(3), 250-265.

Avis, J. (2011). More of the same? New Labour, the Coalition and education: Markets, localism and social justice. Educational Review, 63(4), 421-438.

Ball, S. J. (1993). Education policy, power relations and teachers' work. British Journal of Educational Studies, 41(2), 106-121.

Ball, S. J. (1997). Policy sociology and critical social research: A personal review of recent education policy and policy research. British Educational Research Journal, 23(3), 257-274.

Ball, S. J. (2000). Performativities and fabrications in the education economy: Towards the performative society? The Australian Educational Researcher, 27(2), 1-23.

Ball, S.J. (2003). The teacher's soul and the terrors of performativity. Journal of Education Policy, 18(2), 215-228.

Barnes, A. (1975). Local government and education service. In M. Hughes, \& J. Richards (Eds.), Autonomy and accountability in educational administration.Proceedings of the fourth annual conference of the British educational administration society. (pp. 12-14). London: British Educational Administration Society. 
Benn, C. (1974). England lags behind. Forum for the Discussion of New Trends in Education, $16(3), 68-72$.

Bennett, N. (1984). Central control and parent influence: Reconciling the tensions in current proposals for school governance and policy making. Educational Management \& Administration, 12(3), 157-163.

Bevir, M., \& Trentmann, F. (2004). Markets in historical contexts: Ideas and politics in the modern world. Cambridge: Cambridge University Press.

Bishop, M., \& Green, M. (2015). Philanthrocapitalism rising. Society, 52(6), 541-548.

Blowers, A. (1977). Checks and Balances-The politics of minority government. Public Administration, 55(3), 305-316.

Board of Education (1931). Report of the Consultative Committee on the primary school. London: HM Stationery Office. ('Hadow Report').

Bogdanor, V. (1976). Education. In Blake Lord, \& J. Patten (Eds.). The Conservative opportunity (pp. 117-131). London and Basingstoke: Macmillan Press.

Bogdanor, V. (1979). Power and participation. Oxford Review of Education, 5(2), 157-168.

Boynton, J. K. (1975). Local government and the education service. In H. Meredydd, \& J. Richards (Eds.), Autonomy and accountability in educational administration (pp. 3-6). United Kingdom: British Educational Administration Society.

Bridges, D. (1994). Parents: Customers or partners. In, D. Bridges, \&, T.H. McLaughlin (Eds.), Education and the Market Place. London: Falmer Press, pp.65-79.

Broadfoot, P. (1987). The significance of contemporary contradiction in educational assessment policies in England and wales. Available:

https://files.eric.ed.gov/fulltext/ED305397.pdf [Accessed: 10.01.2018]

Cahill, D. (2013). Ideas-centred explanations of the rise of neoliberalism: A critique. Australian Journal of Political Science, 48(1), 71-84. 
Callaghan, J. (1976). 'Ruskin speech'. Available:

http://www.educationengland.org.uk/documents/speeches/1976ruskin.html [Accessed: 10.01.2018]

Chitty, C. (1997a). Privatisation and marketisation. Oxford Review of Education, 23(1), 45-68.

Chitty, C. (1997b). The school effectiveness movement: Origins, shortcomings and future possibilities. The Curriculum Journal, 8(1), 45-62.

Dale, R. (1981). Education and the state: Politics, patriarchy and practice. London: Taylor \& Francis.

Dale, R. (1989). The Thatcherite project in education: The case of the city technology colleges. Critical Social Policy, 9(27), 4-19.

Davies, J. S. (2004). Conjuncture or disjuncture? An institutionalist analysis of local regeneration partnerships in the UK. International Journal of Urban and Regional Research, 28(3), 570-585.

Davies, J. S. (2005). Local governance and the dialectics of hierarchy, market and network. Policy Studies, 26(3-4), 311-335.

Deem, R., Brehony, K., \& Heath, S. (1994). Governors, schools and the miasma of the market. British Educational Research Journal, 20(5), 535-549.

Department for Education. (DfE) (2010).Free schools. Available: http://www.education.gov.uk/schools/leadership/typesofschools/freeschools/a0061423/freeschools. [Accessed: 10.01.2018]

Department for Education and Employment. (DfEE) (1997). Excellence in schools. London: HMSO.

Department for Education and Employment. (DfEE) (1998). Teachers meeting the challenge of change. London: HMSO. 
Department of Education and Science. (DES) (1978). Report of the committee of inquiry into the special educational needs of children and young people ('warnock report'). London: DES.

Department of Education and Science. (DES) (1981). The school curriculum. London: HMSO.

Department of Education and Science. (DES) (1984). Parental influence at school: A new framework of school government in England and Wales. London: HMSO.

Department of Education and Science. (DES) (1985). Better schools. London: HMSO.

Department of Education and Science. (DES) 1987). Education reform bill. London: HMSO.

Department of Education and Science. (DES) (1988). Education reform act. London: HMSO.

Department of Social Security. (DSS) (1998). New ambitions for our country. London: HMSO.

Donaldson, G. (2010). Teaching Scotland's future. Report of a review of teacher education in Scotland. Edinburgh: Scottish Government.

Draper, J., \& Sharp, S. (2006). Continuity or change? The initial impact of the post-McCrone agreement. Scottish Educational Review, 37(I), 99.

Elliott, J. (1977). The conditions of public accountability. Cambridge Journal of Education, $7(2), 100-104$.

Elliott, J. (1979). The case for school self-evaluation. Forum for the Discussion of New Trends in Education, 22. (1) pp. 23-25.

Evans, J., \& Penney, D. (1994). Whatever happened to good advice? Service and inspection after the Education Reform Act. British Educational Research Journal, 20(5), 519-533.

Friedman, M. (1962). Capitalism and freedom. Chicago: University of Chicago Press.

General Teaching Council for Scotland. (GTCS). (2012a). Standard for career-long professional learning. Edinburgh: GTCS. 
General Teaching Council for Scotland. (GTCS). (2012b). Standards for registration. Edinburgh: GTCS.

General Teaching Council for Scotland. (GTCS). (2012c). Standards for leadership and management. Edinburgh: GTCS.

General Teaching Council for Scotland. (GTCS). (no date.). Advice on professional review and development (PRD). Draft advice note 1.

http://www.eis.org.uk/Glasgow/images/pdf/professional\%20update\%20gtcs\%20draftadvic e\%20note\%201.pdf. [Accessed 09.01.2018].

Gewirtz, S., Dickson, M., \& Power, S. (2004). Unravelling a 'spun' policy: A case study of the constitutive role of 'spin' in the education policy process. Journal of Education Policy, 19(3), 321-342.

Gewirtz, S., Dickson, M., Power, S., Halpin, D., \& Whitty, G. (2005). The deployment of social capital theory in educational policy and provision: The case of education action zones in England. British Educational Research Journal, 31(6), 651-673.

Gillard, D. (2016). Education in England: A brief history . Http://www.Educationengland.Org [Accessed: 10.01.2018].

Ginsburg, M. B., Meyenn, R. J., \& Miller, H. D. (1979). Teachers, the 'Great Debate' and education cuts. Westminster Studies in Education, 2(1), 5-33.

Ginsburg, M., Wallace, G., \& Miller, H. (1988). Teachers, economy, and the state: An english example. Teaching and Teacher Education, 4(4), 317-337.

Glatter, R. (1976). Reforming school management: Some structural issues. Educational Administration, 5(1), 50-56.

Gleeson, D., \& Gunter, H. (2001). The performing school and the modernisation of teachers. In: D. Gleeson, \&, C. Husbands (Eds.)The Performing School: Managing, Teaching, and Learning in a Performance Culture, London: Routledge, Falmer, pp. 139-158. 
Gorard, S. (2005). Academies as the 'future of schooling': Is this an evidence-based policy? Journal of Education Policy, 20(3), 369-377.

Habermas, J. (1973). What does a crisis mean today? Legitimation problems in late capitalism. Social Research, 40(4), 643-667.

Halpin, D. (1979). Accountability, answerability and the reporting of active learning time. British Journal of Teacher Education, 5(3), 199-217.

Hammond, J. (1986). Re-assessing the roles of teachers, parents and governors-symposium paper 3. Educational Management \& Administration, 14(2), 133-138.

Hansard. (1978). http://hansard.millbanksystems.com/commons/1978/jul/18/voucherscheme [Accessed: 02.11.17]

Harris, A., \& Ranson, S. (2005). The contradictions of education policy: Disadvantage and achievement. British Educational Research Journal, 31(5), 571-587.

Higham, R. (2014). 'Who owns our schools?' An analysis of the governance of free schools in England. Educational Management Administration and Leadership, 42(3), 404-422.

HMSO. (1967). Children and their primary schools. (Plowden report). London: HMSO.

HMSO. (1968). The civil service. Report of the committee 1966-1968. London.

http://www.civilservant.org.uk/library/1968 fulton report.html [Accessed: 30.11.17]: HMSO.

HMSO. (1972). Report on the new local authority management and structure. (Baines committee report). London: HMSO.

HMSO (1977a). Education in schools: a consultative document. London: HMSO.

HMSO. (1977b). A new partnership for our schools. London: HMSO. 
Hogan, A. (2016). NAPLAN and the role of edu-business: New governance, new privatisations and new partnerships in Australian education policy. Australian Educational Research, 43(1), 93-110.

Hogwood, B. W. (1997). The machinery of government, 1979-97. Political Studies, 45(4), 704-715.

Jessop, B. (2003). Governance and meta-governance: On reflexivity, requisite variety and requisite irony. In: H.P. Bang (Ed.) Governance as Social and Political Communication. Manchester: Manchester University Press, pp. 101-116.

Johnson, C. \& Tonkiss, F. (2002). The third influence: the Blair government and Australian Labor, Policy and Politics, 30(1), 5-18.

Jonathan, R. (1990). State education service or prisoner's dilemma: The 'Hidden Hand'as source of education Policy1. Educational Philosophy and Theory, 22(1), 16-24.

Jones, K., \& Bird, K. (2000). 'Partnership'as strategy: Public-private relations in education action zones. British Educational Research Journal, 26(4), 491-506.

Judge, H. (1979). After the comprehensive revolution: What sort of secondary schools? Oxford Review of Education, 5(2), 137-146.

Kellner, P. and Crowther-Hunt, N. (1981) Civil Servants: An Inquiry into Britain's Ruling Class. London: Futura Press

Kickert, W. J. (1993). Autopoiesis and the science of (public) administration: Essence, sense and nonsense. Organization Studies, 14(2), 261-278.

Kickert, W. (1991). Applicability of autopoiesis to administration science. Autopoiesis and configuration theory: New approaches to societal steering (pp. 193-205) Dordrecht: Springer.

Kogan, M. (1984). School governing bodies. London: Heinemann Educational Publishers. 
Laclau, E., \& Mouffe, C. (2001). Hegemony and socialist strategy: Towards a radical democratic politics London: Verso.

Lawn, M., \& Grek, S. (2012). Europeanizing education: Governing a new policy space. Oxford: Symposium Books.

Levi-Faur, D. (2012). The Oxford handbook of governance. In D. Levi-Faur (Ed.), (pp. 3-18). Oxford: Oxford University Press.

Levi-Faur, D., \& Jordana, J. (2005). The rise of regulatory capitalism: The global diffusion of a new order. The Annals of the American Academy of Political and Social Science, 598(1), 200217.

Lewis, S., Sellar, S., \& Lingard, B. (2016). PISA for schools: Topological rationality and new spaces of the OECD's global educational governance. Comparative Education Review, 60(1), 27-57.

Lingard, B., Rawolle, S., \& Taylor 1, S. (2005). Globalizing policy sociology in education: Working with Bourdieu. Journal of Education Policy, 20(6), 759-777.

Lingard, B., \& Sellar, S. (2014). Representing your country: Scotland, PISA and new spatialities of educational governance. Scottish Educational Review, 46(1), 5-11.

Lobel, O. (2012). New governance as regulatory governance. In D. Levi-Faur (Ed.), The Oxford handbook of educational governance (pp. 65-82). Oxford: Oxford University Press.

MacBeth, A. (1984). The government of Scottish education: Partnership or compromise. Edinburgh: Unit for the Study of Government in Scotland, University of Edinburgh.

MacDonald, B. (1974). Evaluation and the control of education. University of East Anglia, available: https://ueaeprints.uea.ac.uk/29614/1/MacDonald-1974-

Evaluation and the Control of Education.pdf [Accessed: 09.01.2018] 
Macdonald, B. (1978). Accountability, standards and the process of schooling. University of East Anglia, available: https://ueaeprints.uea.ac.uk/31923/1/MacDonald-1978-

Accountability Standards and the Process of Schooling.pdf [Accessed: 20.11.17]

Macdonald, B. (1979). Hard times: Educational accountability in England. Educational Analysis Journal, 1(1), 23-43.

Mahony, P., Hextall, I., \& Menter, I. (2004). Threshold assessment and performance management: Modernizing or masculinizing teaching in England? Gender and Education, 16(2), 131-149.

Malpas, J., \& Wickham, G. (1995). Governance and failure: On the limits of sociology. The Australian and New Zealand Journal of Sociology, 31(3), 37-50.

Margaret Thatcher Foundation (no date). Available:

https://www.margaretthatcher.org/document/110858 [Accessed: 09.01.2018]

Marinetto, M. (2003). Governing beyond the centre: A critique of the Anglo-Governance school. Political Studies, 51(3), 592-608.

Marx, K. (1852). The eighteenth brumaire of Louis Bonaparte

Available:https://www.marxists.org/archive/marx/works/1852/18th-brumaire/. [Accessed 09.01.2018].

Mason, P. (1975). Educational vouchers under test. Oxford Review of Education, 1(2), 159167.

McKnight, A., Glennerster, H., \& Lupton, R. (2005). Education, education, education... an assessment of Labour's success in tackling education inequalities. Bristol: Policy Press.

Merton, R. K. (1936). The unanticipated consequences of purposive social action. American Sociological Review, 1(6), 894-904.

Minogue, M. (1977). Documents on contemporary British government. Cambridge: Cambridge University Press. 
Munn, P. (1985). Accountability and Parent-Teacher communication. British Educational Research Journal, 11(2), 105-107.

Novak, M. (1999). On cultivating liberty: Reflections on moral ecology. Oxford: Rowman \& Littlefield.

Office of the Deputy Prime Minister (2004). Breaking the cycle. A report by the Social Exclusion Unit. HMSO: London.

O'Hagan, B. (1999). Introduction. In B. O'Hagen (Ed.), Modern educational myths. The future of democratic comprehensive education. (pp. 1-10). London: Kogan Page.

Olkinuora, E. (1973). On the problems of developing educational indicators. Acta Sociologica, 16(4), 284-302.

Olmedo, A. (2014). From England with love...ARK, heterarchies and global 'philanthropic governance'. Journal of Education Policy, 29(5), 575-597.

Organisation for Economic Cooperation and Development. (OECD) (nd). Organisation for economic cooperation and development. Http://www.Oecd.org/about/ [Accessed: 15.12.17]

Organisation for Economic Cooperation and Development. (OECD) (2016). Governing education in a complex world. Paris: OECD.

Organisation for Economic Cooperation and Development. (OECD) (2017). Education at a glance. Available: http://www.oecd-

ilibrary.org/docserver/download/9617041e.pdf?expires=1515487086\&id=id\&accname=gue st\&checksum=AAFD652031307A008861A3B27AF3755E [Accessed: 01.12.2017]

Owen, J. (1978). A new partnership for our schools: The Taylor report. Oxford Review of Education, 4(1), 37-49.

Ozga, J. (2002). Education governance in the United Kingdom: The modernisation project. European Educational Research Journal, 1(2), 331-341. 
Ozga, J., \& Lingard, B. (2007). Globalisation, education policy and politics. In: B. Lingard \& J. Ozga, (Eds) The RoutledgeFalmer Reader in Education Policy and Politics, Abingdon, Oxon: RoutledgeFalmer, pp. 65-82.

Ozga, J., Segerholm, C., \& Simola, H. (2012). The governance turn. In J. Ozga, P. DahlerLarsen, C. Segerholm \& H. Simola (Eds.), Fabricating quality in education. data and governance in europe. (pp. 85-95). London and New York: Routledge.

Parlett, M. \&, Hamilton, D. (1972). Evaluation as illumination: A new approach to the study of innovatory programs. Edinburgh: Centre for Research in the Educational Sciences.

Pascal, C. (1988). Democratised primary school government: Policy in practice. British Educational Research Journal, 14(1), 17-29.

Peck, J. (2010). Constructions of neoliberal reason. Oxford: Oxford University Press.

Peck, J., \& Tickell, A. (2002). Neoliberalizing space. Antipode, 34(3), 380-404.

Peters, B. G. (1994). Managing the hollow state. International Journal of Public Administration, 17(3-4), 739-756.

Peters, G. (2012). Governance as political theory. In D. Levi-Faur (Ed.), The Oxford handbook of governance (pp. 19-32). Oxford: Oxford University Press.

Pierson, C. (1998). The new governance of education: The Conservatives and education 1988-1997. Oxford Review of Education, 24(1), 131-142.

Portes, A. (1998). Social capital: Its origins and applications in modern sociology. Annual Reviews in Sociology, 24(1), 1-24.

Powell, M. (2000). New Labour and the third way in the British welfare state: A new and distinctive approach? Critical Social Policy, 20(1), 39-60.

Power, S., Halpin, D., \& Fitz, J. (1994). Parents, pupils and grant-maintained schools. British Educational Research Journal, 20(2), 209-225. 
Power, S., \& Whitty, G. (1999). New Labour's education policy: First, second or third way? Journal of Education Policy, 14(5), 535-546.

Ranson, S. (1985). Contradictions in the government of educational change. Political Studies, 33(1), 56-72.

Ranson, S. (1986). Towards a political theory of public accountability in education. Local Government Studies, 12(4), 77-98.

Ranson, S. (2003). Public accountability in the age of neoliberal governance. Journal of Education Policy, 18(5), 459-480.

Rhodes, R. A. W. (1996). The new governance: Governing without government. Political Studies, 44(4), 652-667.

Rizvi, F., \& Lingard, B. (2006). Globalization and the changing nature of the OECD's educational work. In: H. Lauder, P. Brown, J-A. Dillabough, \& A.H. Halsey, (Eds). Education, Globalization and Social Change. Oxford: Oxford University Press, pp. 247-260.

Roberts-Holmes, G., \& Bradbury, A. (2017). Primary schools and network governance: A policy analysis of reception baseline assessment. British Educational Research Journal, 43(4),671-682.

Rose, N., \& Miller, P. (1992). Political power beyond the state: Problematics of government. British Journal of Sociology, 43(2), 173-205.

Salter, B., \& Tapper, T. (1981). Education, politics and the state. The theory and practice of educational change. London: Grant McIntyre.

Schneider, L. (1971). Dialectic in sociology. American Sociological Review, 36(4), 667-678.

Scottish Executive Education Department. (SEED) (2001). A teaching profession for the 21st century. (McCrone report). Edinburgh: SEED. 
Scottish Government. (2011). Advancing professionalism in teaching. The report of the review of teacher employment in Scotland. ('McCormac report'). Edinburgh: Scottish Government.

Scottish Government. (2017). Education governance: next steps. Edinburgh: Scottish Government.

Scottish Office Education Department. (SOED) (1994). 5-14 A practical guide. Edinburgh: SOED.

Seldon, M. (1979). Now for education vouchers. Education Training, 21(6), 188-189.

Sellar, S., \& Lingard, B. (2013). PISA and the expanding role of the OECD in global educational governance Oxford: Symposium Books.

Selwyn, N., Henderson, M., \& Chao, S. (2015). Exploring the role of digital data in contemporary schools and schooling-'200,000 lines in an excel spreadsheet'. British Educational Research Journal, 41(5), 767-781.

Shepherd, J. (2010). Academies bill is anti-democratic, lawyers warn. Guardian, https://www.theguardian.com/education/2010/jun/06/academies-bill-gove-teachersauthorities [Accessed: 10.01.2018]

Stoker, G. (2002). Life is a lottery: New Labour's strategy for the reform of devolved governance. Public Administration, 80(3), 417-434.

Taylor, A. (2000). Hollowing out or filling in? Taskforces and the management of crosscutting issues in British government. The British Journal of Politics and International Relations, 2(1), 46-71.

Tomlinson, S. (2003). New Labour and education. Children \& Society, 17(3), 195-204.

Troman, G. (1989). Testing tensions: The politics of educational assessment. British Educational Research Journal, 15(3), 279-295. 
Vincent, C., Evans, J., Lunt, I., \& Young, P. (1994). The market forces? the effect of local management of schools on special educational needs provision. British Educational Research Journal, 20(3), 261-277.

Walford, G. (2000). From city technology colleges to sponsored grant-maintained schools. Oxford Review of Education, 26(2), 145-158.

Watson, C. (2010). Educational policy in Scotland: Inclusion and the control society. Discourse: Studies in the Cultural Politics of Education, 31(1), 12.

Watson, C. (forthcoming). Kenneth Burke's perspective by incongruity in the performance of dialectical ironic analysis: A disciplined approach.

Watson, C., \& Drew, V. (2014). Teachers' desire for career-long learning: Becoming 'accomplished' - and masterly.... British Educational Research Journal,

Watson, C., \& Fox, A. (2015). Professional re-accreditation: Constructing educational policy for career-long teacher professional learning. Journal of Education Policy, 30(1), 132-144.

Watson, C., \& Michael, M. K. (2016). Translations of policy and shifting demands of teacher professionalism: From CPD to professional learning. Journal of Education Policy, 31(3), 259274.

Watson, C. (2018). What are schools for these days? The myth of data... Faculty of Social Sciences Blog, University of Stirling. Available: http://foss.stir.ac.uk/2018/01/24/whatare-schools-for-these-days-the-myth-of-data/ [Accessed: 11 May 2018]

Watson, K. (1978). Accountability in English education. Educational Administration, 6(2), 923.

West, A. (2015). Education policy and governance in England under the coalition government (2010-15): Academies, the pupil premium, and free early education. London Review of Education, 13(2), 21-36. 
West, E. G. (1982). Education Vouchers-Evolution or revolution? Economic Affairs, 3(1), 1419.

Wilkins, A. (2012). Public battles and private takeovers: Academies and the politics of educational governance. Journal of Pedagogy, 3(1), 11-29.

Williamson, B. (2016a). Digital education governance: Data visualization, predictive analytics, and 'real-time' policy instruments. Journal of Education Policy, 31(2), 123-141.

Williamson, B. (2016b). Boundary brokers: Mobile policy networks, database pedagogies, and algorithmic governance in education. Research, boundaries, and policy in networked learning (pp. 41-57) Dordrecht: Springer.

Williamson, B. (2017). Big data in education: The digital future of learning, policy and practice London: Sage.

Wilson, A., Watson, C., Thompson, T. L., Drew, V., \& Doyle, S. (2017). Learning analytics: Challenges and limitations. Teaching in Higher Education, 22(8),991-1007. 